\title{
The Supreme Court of Canada and the Alberta COURT OF APPEAl: Do THE TOP COURTS have a Fundamental Philosophical Difference of Opinion on Public Law Issues?
}

\author{
Barbara Billingsley and Bruce P. ElmaN
}

Prompted by the marked clash between the Supreme Court of Canada and the Alberta Court of Appeal in R. v. Ewanchuk, the authors ask whether this conflict is indicative of a fundamental divergence of opinion between the two courts. To answer this question, the authors embark on a review of all 132 public law cases appealed from the Alberla Court of Appeal to the Supreme Court of Canada between 1982 and December 2000. The authors examine these cases to determine the extent of the Supreme Court's overt criticism of the reasoning employed by the Alberta Court of Appeal.

While acknowledging the obvious difficulties of subjecting this data to precise analysis, the authors find that the data reveals some predictable patterns regarding the manner in which the two courts react to certain public law questions. The authors conclude that there are some fundamental philosophical differences between the courts, a finding which indicates that the clash between the courts in the Ewanchuk case was not a completely unique or unpredictable circumstance.
Inspirés par le conflit choquant entre la Cour suprème du Canada et la Cour d'appel de l'Alberta dans R. contre Ewanchuk, les auteurs se demandent si ce conflit est indicatif de la divergence d'opinions entre les deux cours. Afin de répondre à cette question, les auteurs ont revu les 132 causes de droit public qui ont fait l'objet d'un appel de la Cour d'appel de l'Alberta devant la Cour suprême du Canada entre 1982 et décembre 2000. Les auteurs étudient ces causes pour déterminer l'étendue de la critique flagrante de la Cour suprème sur le raisonnement de la Cour d'appel de I'Alberla.

Tout en reconnaissant qu'il est difficile de soumettre ces données à des analyses précises et scientifiques, les auteurs estiment que les données révèlent certains modèles prévisibles dans la manière dont les deux cours réagissent aux questions de droit public. Les auteurs concluent qu'il existe certaines différences philosophiques fondamentales entre les cours, ce qui indique que le conflit entre elles quant à l'affaire Ewanchuk n'était pas tout à fait unique or imprévisible.

\section{TABLE OF CONTENTS}

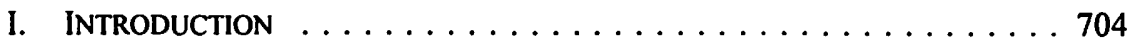

II. THE Research Parameters $\ldots \ldots \ldots \ldots \ldots \ldots \ldots \ldots$

III. WHAT Do THE NUMBERS SAY? THE EMPIRICAL DATA . . . . . . 708

IV. BEYOND THE NUMBERS: THE SUBSTANCE OF THE

SUPREME COURT'S NEGATIVE COMMENTARY $\ldots \ldots \ldots \ldots \ldots 718$

A. Classifying the Negative Commentary CASES ....... 718

B. MORE ON THE THIRD CLASS: TONE OF THE

Negative Comments . . . . . . . . . . . . . 719

C. THE RELATIONSHIP BETWEeN THE RESULT OF THE APPEAL

AND the TONE OF the Negative CoMment . . . . . . . . 724

Barbara Billingsley, Assistant Professor, Faculty of Law, University of Alberta; and Bruce P. Elman, Professor and Dean, Faculty of Law, University of Windsor (formerly Belzberg Professor of Constitutional Law, University of Alberta). The writers would like to acknowledge the invaluable work of Jeff Landmann, from the University of Alberta, who served as the primary research assistant for this article. The research was funded by a Small Faculties Research Grant from the University of Alberta. Thanks also to Marco Mendicino, from the Faculty of Law at the University of Windsor, who provided editorial assistance. 
D. THE Relationship BETWEen the TOPIC CONSIDERED AND THE TONE OF THE NEGATIVE COMMENT . . . . . . . . 724

V. POSITIVE FEEDBACK: COMPLIMENTS FROM THE

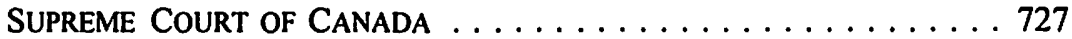

VI. MEANING AND MESSAGE: ANALYZING the DATA $\ldots \ldots \ldots \ldots 728$

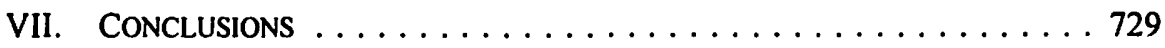

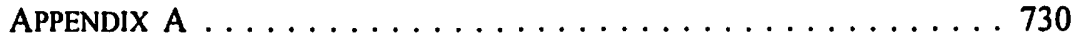

\section{INTRODUCTION}

In late February of 1999 the Supreme Court of Canada decided to overturn the verdict of the Alberta Court of Appeal in the case of $R$. v. Ewanchuk.' This decision and its aftermath focused national attention on the relationship between the two courts involved in the case. Although the Supreme Court's finding was arguably worthy of some attention, the public furor that ensued, both within Alberta's legal profession and among the general public, was primarily generated by the harsh exchange of comments between Justice Claire L'Heureux-Dubé of the Supreme Court and Justice John McClung of the Alberta Court of Appeal.

The two justices were openly and expressly critical of each other's views. In her written judgment in the Ewanchuk case, Justice L'Heureux-Dubé contended that the opinions expressed by Justice McClung in the Appeal Court ruling were derived not from the findings of fact "but from mythical assumptions." 2 Further, Justice L'Heureux-Dubé argued that Justice McClung's statements perpetuated "archaic myths and stereotypes."” Justice McClung, in a highly unusual response, defended his judgment in a letter and interview published by the National Post. He accused Justice L'Heureux-Dubé of using her judicial position to advance her personal opinions. ${ }^{4}$

Justice McClung's reaction to Justice L'Heureux-Dubé'sjudgment drew public attention to the Supreme Court's criticism of the Court of Appeal's decision in Ewanchuk. The letter and interview spurred a vigorous public debate on whether the justices had acted appropriately in criticizing one another. More particularly, the controversy focused on whether Justice L'Heureux-Dubé's critique of Justice McClung's views was unnecessarily personal and harsh. The critical issues raised by Justice L'Heureux-Dubé's comments, however, go beyond questions of judicial protocol and centre, more particularly, on the question of what, if anything, these comments reveal about the interaction between the

[1999] 1 S.C.R. 330, rev'g (1998), 212 A.R. 81 [hereinafter Ewanchuk].

Ibid. at 372.

Ibid. at 376.

Mr. Justice J.W. McClung, Letter to the Editor, National Post (26 February 1999) A19: "Madame Justice Claire L'Heureux-Dube's graceless slide into personal invective in Thursday's judgment in the Ewanchuk case allows some response. It issued with "the added bitterness of an old friend." Whether the Ewanchuk case will promote the fundamental right of every accused Canadian to a fair trial will have to be left to the academics. Yet there may be one immediate benefit. The personal convictions of the judge, delivered again from her judicial chair, could provide a plausible explanation for the disparate (and growing) number of male suicides being reported in the Province of Quebec." 
Alberta Court of Appeal and the Supreme Court of Canada. Is the Supreme Court's harsh criticism of the Alberta Court of Appeal in Ewanchuk unique, or is it merely the latest, albeit the most conspicuous, example of a recurring, pervasive, and fundamental clash of public policy perspectives between the Supreme Court of Canada and the Alberta Court of Appeal? If a fundamental divergence on public policy matters does exist between the two courts, what are the points of disagreement, and what, if any, consequences flow from this division? In attempting to answer these fundamental questions, this article will consider both the empirical data regarding Alberta appeals to the Supreme Court of Canada and the substantive comments made by the Supreme Court of Canada when considering public law cases from Alberta. ${ }^{5}$ This article goes beyond simply reviewing the empirical data regarding the success rate of Alberta appeals to the Supreme Court of Canada. While such data is useful, it does not reveal much about the fundamental public policy perspectives from which each court operates. Accordingly, in an attempt to shed some light on the relationship between the Alberta Court of Appeal and the Supreme Court of Canada regarding public policy matters, this article considers both the empirical data regarding the frequency of the Supreme Court's overt criticism of the Alberta Court of Appeal in public law cases and the substantive content of this criticism.

\section{The Research Parameters}

This article is based on a review of all the public law cases appealed from the Alberta Court of Appeal to the Supreme Court of Canada since the 1982 advent of the Canadian Charter of Rights and Freedoms ${ }^{6}$ up to and including December 2000 . For the purpose of this analysis, a "public law" case is defined as any case involving a significant public law element; that is, any case involving public policy issues between levels of government or between government and private citizens or corporations. The research, therefore, includes all criminal law cases and all constitutional law cases. Cases on sentencing matters $^{7}$ and cases that raise administrative or procedural questions absent any constitutional or Charter issues have been excluded. Alberta applications for leave to appeal to the Supreme Court of Canada have also been excluded. ${ }^{8}$

Several other empirical studies have been written with respect to Supreme Court of Canada appeal rates and success rates. Most notable are the publications of Peter J. McCormick, including: "Alberta's Court of Next-To-Last Resort: Appeals from the Alberta Court of Appeal to the Supreme Court of Canada, 1970-1990" (1991) 29 Alta. L. Rev. 861; Canada's Courts, (Toronto: James Lorimer, 1994); "Judicial Citation. The Supreme Court of Canada, and the Lower Courts: The Case of Alberta" (1996) 34 Alta. L. Rev. 870; and I. Greene et al., Final Appeal: Decision-Making in Canadian Courts of Appeal (Toronto: James Lorimer, 1998).

6 Part I of the Constitution Act. 1982, being Schedule B to the Canada Act 1982 (U.K.). 1982, c.1I [hereinafter Charter].

7 The sentencing matters were originally excluded as being beyond the intended parameters of this study. In any event, preliminary research indicated that all sentencing appeals that raised Charter questions have been denied leave by the Supreme Court.

* The outcome of leave applications cannot be relied upon as a basis for analyzing the fundamental philosophical perspectives of the Alberta Court of Appeal and the Supreme Court of Canada because the Supreme Court is under no legal obligation to give reasons for granting or refusing leave to appeal. In fact, the Supreme Court frequently does not provide such reasons. Further. as noted by P.W. Hogg, Constitutional Law of Canada, 4th ed. vol. I looseleaf (Scarborough: Carswell. 1998 Rel. 1) at 8-12: "Because the Court does not give reasons for the grant or denial of leave to appeal, there is no case law on the kinds of considerations that the Court takes into account in determining applications for leave." 
The decision to restrict this article to an analysis of public law cases since the advent of the Charter is a purposeful one. Although private law cases - contract, property, and tort law disputes, for example - often raise public policy matters, ${ }^{9}$ public law cases more frequently and obviously raise such issues, providing the courts with an opportunity to comment directly on public policy matters. Further, while the public law cases considered for this study are not restricted to Charter cases, the time span encompassed by the research intentionally coincides with the inception of the Charter because the adoption of the Charter fundamentally expanded the mandate and ability of Canadian courts to analyze government policy and public law matters. Accordingly, one premise of this research is that since 1982 all public law matters before the courts have necessarily involved an express or implied consideration of Charter values and, therefore, have increased the potential for conflict between the fundamental philosophies of the provincial courts of appeal and the Supreme Court of Canada.

As noted above, the research for this article focuses on identifying and substantively analyzing public law cases in which the Supreme Court of Canada has criticized the reasoning of the Alberta Court of Appeal, regardless of whether the appeal was successful or not. To some extent the process of identifying these cases is a subjective exercise, unavoidably affected by the perspective of the person reading the cases. For example, one reader might argue that every case in which the Supreme Court rejects the findings or the reasoning of the Alberta Court of Appeal is by definition a case in which the Supreme Court negatively comments on the lower court's reasoning. Further, different readers might have different opinions as to what constitutes a "negative" comment or criticism by the Supreme Court of Canada. Comments that one reader might take to be negative might not appear so to another reader. As much as possible, this study attempts to minimize the impact of subjective influences on the data collection process by relying only on those cases in which the Supreme Court expressly rejects, challenges, or questions the reasoning of the Alberta Court of Appeal (even if the Supreme Court agrees with the ultimate finding in the case).

As a template for identifying those cases in which the Supreme Court openly criticizes the reasoning of the Alberta Court of Appeal, this study relies upon examples drawn from $R$. v. Ewanchuk, ${ }^{10}$ Vriend v. Alberta, ${ }^{11}$ and $R$. v. Westendorp. ${ }^{12}$ As previously noted, in Ewanchuk Justice L'Heureux-Dubé of the Supreme Court criticized Justice McClung's statements in the appeal judgment as perpetuating "archaic myths and stereotypes." ${ }^{13}$ In Vriend Justices Cory and Iacobucci of the Supreme Court noted that Justice McClung was "mistaken" in his interpretation of the law and expressly disagreed with various aspects of the lower court's reasoning. ${ }^{14}$ In Westendorp Chief Justice Laskin of the Supreme

"There are a myriad of private law cases that raise public policy issues. Some prominent examples include: Citizens Insurance Company v. Parsons (1881), 7 App. Cas. 96; Starr v. Houlden, [1990] I S.C.R. 1366; Hill v. Church of Scientology, [1995] 2 S.C.R. I130; and Dobson v. Dobson, [1999] 2 S.C.R. 753.

III Supra note 1.

" [1998] I S.C.R. 493, rev'g (1996), 184 A.R. 351 [hereinafter Vriend].

12 [1983] 1 S.C.R. 43, rev'g (1982), 35 A.R. 228 [hereinafter Westendorp].

1. Supra note I at 376.

is $\quad$ Supra note 11 at 548. 
Court characterizedthe analysis of Justice Kerans of the Alberta Court as being "baffling" and "doubly baffling." 15

Of course, such negative comments by the Supreme Court are only one indicia of a fundamental philosophical difference of opinion between the Supreme Court and the Alberta Court of Appeal. Again, one could argue that every time the Supreme Court overturns a decision of the Alberta Court of Appeal, the Supreme Court is implicitly demonstrating a philosophical divergence from the Alberta Court even though there is no express criticism of the Alberta Court's approach. Accordingly, a fundamentally divergent philosophical perspective might exist between the courts even absent express negative comments by the Supreme Court of Canada. Nevertheless, it is reasonable, if not obvious, to assume that the Supreme Court of Canada's express criticism of the Alberta Court is the best objective indicator of the Supreme Court's opinion of the soundness of the Alberta Court's reasoning. First, pointed and critical comments by the Supreme Court are a clear indication of a difference of opinion between the courts. Second, critical commentary by the Supreme Court provides an insight into the Supreme Court's opinion of the Alberta Court's approach, regardless of whether the two courts ultimately agree on the disposition of a given case. Finally, since the Supreme Court is always in a position to comment on the reasoning employed by a lower court, the fact that the Supreme Court chooses to overtly criticize the Alberta Court's judgment in some cases but not in others may help to identify the public policy issues on which the Supreme Court and the Alberta Court of Appeal most often or most strongly diverge.

Because this analysis goes beyond a review of empirical data alone, certain limitations on its conclusions must be recognized at the outset. First, and most obviously, all of the data involved in this study is unavoidably affected by several "outside factors," including the number of public law issues arising in the courts, the number of public law cases pursued to appeal, and the number of public law cases in which leave was granted by the Supreme Court of Canada. In other words, this inquiry into the fundamental philosophical perspectives of the Alberta Court of Appeal and the Supreme Court of Canada and the divergence, if any, between them is limited to a review of the cases actually heard by both courts. Again, while a philosophical difference may exist between the courts apart from these cases, this article necessarily relies on the case law as the one, and perhaps the only, objective evidence of such a difference. ${ }^{16}$

Second, the Supreme Court's express criticisms of the Alberta Court of Appeal are undoubtedly affected by two highly subjective elements: specifically, the nature of the public law question before the court and the temperament of the judges writing the decisions. Some questions are inherently more politically, emotionally, or passionately charged than others and, therefore, more easily lend themselves to overt criticism of a

Supra note 12 at 53.

Until recently Canadian judges have not generally spoken out in public. When they have, they generally tend to avoid controversial matters. In particular, judges rarely speak on the decisions of other courts. The tendency of judges to avoid publicly commenting on cases is precisely what made Justice McClung's letter to the National Post regarding Ewanchuk so extraordinary and is what ultimately prompted calls for an investigation into the appropriateness of Justice McClung's conduct in writing the letter. 
lower court's reasoning. Similarly, some judges are naturally more impassioned or more aggressive writers and, therefore, are more likely to expressly - and negatively comment on reasoning with which they disagree. These subjective elements arguably limit any objective analysis of the fundamental philosophical positions of the Supreme Court of Canada and the Alberta Court of Appeal. Further, these elements also provide a basis for assessing whether the Supreme Court's criticism in a case such as Ewanchuk reflects a clash of fundamental values between the courts or merely a clash of judicial personalities. Accordingly, to the extent possible, this study attempts to take these elements into account.

Finally, the data collected for this study includes only the comments made by the Supreme Court of Canada about the Alberta Court of Appeal's reasoning. The study does not include an evaluation of comments that appear in judgments from the lower court about the Supreme Court's analysis in previous cases. While such information may provide meaningful insight into the public policy perspectives of the two courts, gathering such data was beyond the scope of this article. Similarly, this article does not attempt to assess the relationship between the Supreme Court of Canada and any other provincial or territorial Court of Appeal or the Federal Court of Appeal. It might be that the members of the Supreme Court of Canada are no more expressly critical of the Alberta Court of Appeal than they are of other Courts of Appeal. Once again, while such information would be valuable in further analyzing the Supreme Court's relationship to the Alberta Court of Appeal, such an assessment is beyond the scope of this article.

\section{What Do the numbers Say? The Empirical Data}

Of all the cases appealed from the Alberta Court of Appeal to the Supreme Court of Canada from 1982 to December 2000, 132 cases fit into the public law category as defined in this article. ${ }^{17}$ These cases are further subcategorized based upon the issue of appeal: Charter, non-Charter constitutional law, and all other public law issues. Cases involving non-Charter constitutional issues raise questions of general constitutional interpretation, typically, although not exclusively, involving an interpretation of the division of powers between the orders of government created by the Canadian Constitution, including primarily the Constitution Act, $1867^{18}$ and the Constitution Act, $1982 .{ }^{19}$ Cases appealed on "other public law issues" do not involve Charter or nonCharter constitutional law questions. Accordingly, this category involves a mixed bag of issues, mostly concerning the interpretation of federal or provincial statutes.

As illustrated in Figure I, of the 132 public law cases 47 cases ( 35 percent) were appealed on Charter questions, 10 cases ( 8 percent) concerned non-Charter constitutional issues, and 75 cases ( 57 percent) involved other public law issues. Overall, 54 cases ( 41 percent) were successful on appeal, and 78 (59 percent) were dismissed. Of the successful

See Part II: Research Parameters for a definition of "public law" cases. Note that this article does not distinguish between cases in which the government is the appellant as opposed to the respondent on the appeal. For a list of all 132 cases see Appendix A to this article.

I*

19 (U.K.), 30 \& 31 Vict., c. 3, reprinted in R.S.C. 1985, App. II, No. 5.

Being Schedule B to the Canada Act 1982 (U.K.). 1982, c. 11. 
appeals 20 (37 percent) involved Charter issues, 5 ( 9 percent) involved non-Charter constitutional issues, and 29 (54 percent) concerned other public law issues. Of the unsuccessful appeals 27 cases ( 35 percent) involved Charter questions, 5 cases (6 percent) involved non-Charter constitutional law issues, and 46 cases ( 59 percent) involved other issues. As a basic starting point, these numbers suggest that the Supreme Court of Canada has been fairly even-handed in allowing and dismissing appeals from Alberta - the success and failure rates in public law appeals are not significantly different. That is, the Supreme Court of Canada is almost as likely to allow an appeal from the Alberta Court of Appeal as to reject or dismiss such an appeal. Further, the likelihood of success or failure on appeal is not substantially affected by the type of public law issue under consideration. Regardless of whether the appeal is allowed or disallowed, more than half of the Court's agenda concerns cases that consider general or "other" public law issues, with Charter cases accounting for more than one-third of the agenda and non-Charter constitutional cases comprising less than one-tenth of the cases considered by the Supreme Court.

\section{figure I: Total Public Law Cases Considered}

\begin{tabular}{|c|c|c|c|c|}
\hline & $\begin{array}{l}\text { All Public } \\
\text { Law Cases }\end{array}$ & Charter Cases & $\begin{array}{c}\text { Non-Charter } \\
\text { Constitutional } \\
\text { Cases }\end{array}$ & "Other" Cases \\
\hline Total Cases & 132 & 47 ( $35 \%$ of total) & $10(8 \%$ of total $)$ & $75(57 \%$ of total) \\
\hline Appeals Allowed & $54(41 \%$ of total) & $\begin{array}{l}20 \text { (43\% of ('hurrer } \\
\text { cases) } \\
\text { (37\% of Appeals } \\
\text { Allowed) } \\
(15 \% \text { of total) }\end{array}$ & $\begin{array}{l}5 \text { ( } 50 \% \text { of Non. } \\
\text { (hurrer } \\
\text { Constitutional Law } \\
\text { cases) } \\
(9 \% \text { of Appeals } \\
\text { Allowed) } \\
\text { (4\% of total) }\end{array}$ & $\begin{array}{l}29 \text { (39\% of Other } \\
\text { Cases) } \\
\text { ( } 54 \% \text { of Appeals } \\
\text { Allowed) } \\
(22 \% \text { of total) }\end{array}$ \\
\hline Appeals Dismissed & $78(59 \%$ of total) & $\begin{array}{l}27(57 \% \text { of ( hurrer } \\
\text { cases) } \\
\text { (35\% of Appeals } \\
\text { Dismissed) } \\
(20 \% \text { of total) }\end{array}$ & $\begin{array}{l}5(50 \% \text { of Non- } \\
\text { (harter } \\
\text { Constitutional L.aw } \\
\text { cases) } \\
\text { (6\% of Appeals } \\
\text { Dismissed) } \\
\text { (4\% of total) }\end{array}$ & $\begin{array}{l}46(61 \% \text { of Other } \\
\text { cases) } \\
(59 \% \text { of Appeals } \\
\text { Dismissed) } \\
(35 \% \text { of total) }\end{array}$ \\
\hline
\end{tabular}

As indicated in Figure 2, of the 132 public law cases 21 (16 percent) include express negative commentary by the Supreme Court of Canada regarding the reasoning of the Alberta Court of Appeal. ${ }^{20}$ Trying to evaluate whether this number alone indicates that the Supreme Court of Canada is prone to disagree with the Alberta Court of Appeal on public law matters is a bit like deciding whether the proverbial glass is half empty or half full. On one hand, the 16 percent rate of negative criticism may not seem very significant. On the other hand, this figure does indicate that the Supreme Court has overtly criticized the Alberta Court of Appeal in nearly one-fifth of the Alberta public law cases heard by the Supreme Court over an eighteen-year period. From this perspective, the 16 percent 
figure is arguably quite significant when one takes into account the conservatism usually expected of a superior court when reviewing a lower court's reasoning. At the very least, this criticism rate indicates that the Supreme Court's overt criticism of the Alberta Court of Appeal on public law matters is closer to being a pattern of behaviour or a regular occurrence rather than an isolated incident. ${ }^{21}$

\section{Figure 2: Negative Comment CaSes by Issue}

\begin{tabular}{|l|l|l|l|l|}
\hline & \multicolumn{1}{|c|}{ All Cases } & \multicolumn{1}{|c|}{ Charter Cases } & \multicolumn{1}{|c|}{$\begin{array}{l}\text { Non-Charter } \\
\text { Constitutional } \\
\text { Law Cases }\end{array}$} & “Other" Cases \\
\hline $\begin{array}{l}\text { Number of } \\
\text { Negative Comment } \\
\text { Cases }\end{array}$ & $21(100 \%)$ & $3(14 \%)$ & $5(24 \%)$ & $13(62 \%)$ \\
\hline $\begin{array}{l}\% \text { of Total Cases } \\
\text { Considered }\end{array}$ & $16 \%$ & $2 \%$ & $4 \%$ & $10 \%$ \\
\hline $\begin{array}{l}\% \text { of Cases by } \\
\text { Issue }\end{array}$ & $n / a$ & $\begin{array}{l}6 \% \text { of All Charter } \\
\text { Cases }\end{array}$ & $\begin{array}{l}50 \% \text { of All Non- } \\
\text { Churtur } \\
\text { Constitutional Law } \\
\text { Cases }\end{array}$ & $\begin{array}{l}17 \% \text { of All Other } \\
\text { Cases }\end{array}$ \\
\hline
\end{tabular}

Of the 21 cases containing express negative commentary 3 (14 percent) involved Charter issues, 5 ( 24 percent) involved non-Charter constitutional law cases, and 13 (62 percent) concerned other matters. Looking at these numbers in another way, only 3 (2 percent) of the 132 cases involved negative commentary on Charter issues. Of the Charter cases alone, only 6 percent included negative commentary. Only 5 ( 4 percent) of the 132 cases identified included negative commentary on non-Charter constitutional law issues. Thus negative comments were made in 50 percent of all non-Charter constitutional law cases. Only 13 (10 percent) of the 132 cases included negative commentary on other public law issues. Therefore, negative comments were made in 17 percent of cases concerning other public law issues.

Taken together, the data in Figure 1 and Figure 2 do not demonstrate a correlation between the frequency of the issues raised in public law cases appealed to the Supreme Court and the incidence of the Court's negative commentary with respect to those issues. For example, while Charter issues were raised in more than one-third of all the cases appealed (whether the appeal was successful or not), Charter cases comprised less than one-fifth of the cases containing negative comments by the Supreme Court. Thus in terms of frequency of appeal to the Supreme Court of Canada Charter cases ranked second among the three types of public law issues. However, these cases were the least likely to attract negative commentary from the Supreme Court of Canada. Further, while non-

21 Of course, more meaning could be attached to this figure if it was compared to the rate of express criticism by the Supreme Court of Canada in public law matters appealed from the Courts of Appeal in all other provinces. See Part II: Research Parameters and Part VII: Conclusions for further discussion of this point. 
Charter constitutional law cases comprised less than one-tenth of all public law cases heard by the Supreme Court of Canada, these cases constituted nearly one-quarter of all public law cases containing negative comments. Looked at another way, the Supreme Court negatively commented on the Court of Appeal's reasoning in half of the nonCharter constitutional law cases appealed to the upper court. Thus cases containing nonCharter constitutional law issues were the least likely of the three public law categories to be appealed to the Supreme Court of Canada, but these cases were, by far, the most likely to result in overt criticism by the Supreme Court.

In terms of appeal success rates, Figure 3 shows that appeals were successful in 12 (57 percent) of the 21 negative comment cases. Of these 12 only 1 (8 percent) involved Charter issues, 2 (17 percent) involved non-Charter constitutional law issues, and 9 (75 percent) involved other public law issues. Figure 4 indicates that the appeals were dismissed in 9 (43 percent) of the negative comment cases. Of these 9 cases 2 (22 percent) involved Charter questions, 3 (33 percent) involved non-Charter constitutional law issues, and 4 (45 percent) involved other public law matters. Contrary to expectations, these numbers demonstrate that the Supreme Court was as likely to offer negative comments when dismissing appeals as when allowing them. Further, these numbers indicate that the Supreme Court was least likely to criticize the Alberta Court of Appeal in Charter cases and most apt to criticize the Alberta Court of Appeal in cases raising "other" public law issues, regardless of whether the appeal was dismissed or allowed.

Curiously these numbers show that the Supreme Court criticized the Alberta Court of Appeal on Charter issues twice as frequently when the appeal was dismissed as when the appeal was allowed. ${ }^{22}$ In cases raising "other" public law issues the situation is reversed: the Supreme Court commented negatively on the Alberta Court's reasoning nearly twice as often when the appeal was allowed rather than dismissed. In cases involving nonCharter constitutional law issues, the Supreme Court was one and a half times more likely to criticize the Court of Appeal's reasoning when the appeal was dismissed than when the appeal was allowed. whether the negative comments are made in the majority or dissenting reasons. 
Figure 3: Negative Comment CaSes With APPEAlS Allowed

\begin{tabular}{|l|l|l|l|l|}
\hline & $\begin{array}{c}\text { All } \\
\text { Cases }\end{array}$ & Charter ("C") Cases & $\begin{array}{l}\text { Non-Charter } \\
\text { Constitutional } \\
\text { ("NCC") Law } \\
\text { Cases }\end{array}$ & "Other" Cases \\
\hline $\begin{array}{l}\text { Negative Comment Cases with } \\
\text { Appeals Allowed }\end{array}$ & $\begin{array}{l}12 \\
(57 \%)\end{array}$ & $1(5 \%)$ & $2(9 \%)$ & $9(43 \%)$ \\
\hline$\%$ of Total Cases Considered & $9 \%$ & $1 \%$ & $2 \%$ & $7 \%$ \\
\hline $\begin{array}{l}\% \text { of Negative Comment Cases } \\
\text { with Appeals Allowed }\end{array}$ & $100 \%$ & $8 \%$ & $17 \%$ & $75 \%$ \\
\hline$\%$ by Issue & $n / a$ & $\begin{array}{l}2 \% \text { of all C Cases } \\
33 \% \text { of C Cases } \\
\text { with Negative } \\
\text { Comment }\end{array}$ & $\begin{array}{l}20 \% \text { of all NCC } \\
\text { Law Cases } \\
40 \% \text { of NCC Law } \\
\text { Cases with Negative } \\
\text { Comment }\end{array}$ & $\begin{array}{l}12 \% \text { of all Other } \\
\text { Cases } \\
69 \% \text { of Other Cases } \\
\text { with Negative } \\
\text { Comment }\end{array}$ \\
\hline
\end{tabular}

Figure 4: Negative Comment Cases with APPeals Dismissed

\begin{tabular}{|c|c|c|c|c|}
\hline & $\begin{array}{r}\text { All } \\
\text { Cases }\end{array}$ & Charter ("C") Cases & $\begin{array}{c}\text { Non-Charter } \\
\text { Constitutional } \\
\text { ("NCC") Law Cases }\end{array}$ & "Other" Cases \\
\hline $\begin{array}{l}\text { Negative Comment Cases with } \\
\text { Appeals Dismissed }\end{array}$ & $\begin{array}{l}9 \\
(43 \%)\end{array}$ & $2(9 \%)$ & $3(15 \%)$ & $4(19 \%)$ \\
\hline$\%$ of Total Cases Considered & $6 \%$ & $1 \%$ & $2 \%$ & $3 \%$ \\
\hline $\begin{array}{l}\% \text { of Negative Comment Cases } \\
\text { with Appeals Dismissed }\end{array}$ & $100 \%$ & $22 \%$ & $33 \%$ & $45 \%$ \\
\hline$\%$ by lssue & $\mathrm{n} / \mathbf{a}$ & $\begin{array}{l}4 \% \text { of all C Cases } \\
67 \% \text { of C Cases with } \\
\text { Negative Comment }\end{array}$ & $\begin{array}{l}30 \% \text { of all NCC Law } \\
\text { Cases } \\
60 \% \text { of NCC Law } \\
\text { Cases with Negative } \\
\text { Comment }\end{array}$ & $\begin{array}{l}5 \% \text { of all Other } \\
\text { Cases } \\
31 \% \text { of Other Cases } \\
\text { with Negative } \\
\text { Comment }\end{array}$ \\
\hline
\end{tabular}

Notably, the Supreme Court's criticism did not always appear in the Court's deciding, or majority, judgment. ${ }^{23}$ Figures 5 and 6 illustrate that, of the 21 Supreme Court of Canada public law cases that expressly criticized the reasoning of the Alberta Court of Appeal, in 13 cases (62 percent) the criticism appeared in the majority or concurring judgments, while in 8 (38 percent) the criticism appeared in a dissenting or partially dissenting judgment. Of the 12 cases that contained negative commentary and in which the appeal was allowed, 9 cases ( 75 percent) included negative commentary in the majority reasons, and 3 ( 25 percent) included negative commentary in the dissenting 
reasons. Of the 9 negative commentary cases in which the appeal was dismissed, 4 cases (44 percent) included negative commentary in the majority reasons and 5 (56 percent) included negative commentary in the dissenting reasons. Thus as one might expect, where an appeal was allowed the Supreme Court's overt criticism most often occurred in its majority judgment. But where an appeal was dismissed the Supreme Court's criticism appeared nearly as often in the majority judgment as in the dissenting reasons.

\section{FIGURE 5: Negative COMMENTARY IN MAJORITY REASONS}

\begin{tabular}{|c|c|c|c|c|}
\hline & All Issues & Charter Cases & $\begin{array}{c}\text { Non-Charter } \\
\text { Constitutional Law } \\
\text { Cases }\end{array}$ & "Other" Cases \\
\hline $\begin{array}{l}\text { Comment In } \\
\text { Majority Reasons }\end{array}$ & $13(62 \%)$ & $2(9 \%)$ & $3(15 \%)$ & $8(38 \%)$ \\
\hline $\begin{array}{l}\% \text { of Cases with } \\
\text { Negative } \\
\text { Commentary In } \\
\text { Majority Reasons }\end{array}$ & $100 \%$ & $15 \%$ & $23 \%$ & $62 \%$ \\
\hline $\begin{array}{l}\text { Comment in } \\
\text { Majority Reasons } \\
\text { \& Appeal Allowed }\end{array}$ & $\begin{array}{l}9 \\
\text { ( } 75 \% \text { of cases with } \\
\text { negative comment } \\
\text { where appeal is } \\
\text { allowed) }\end{array}$ & $\begin{array}{l}1 \\
\text { ( } 8 \% \text { of cases with } \\
\text { negative comment } \\
\text { where appeal is } \\
\text { allowed) } \\
\text { ( } 11 \% \text { of cases with } \\
\text { negative comment in } \\
\text { majority reasons \& } \\
\text { appeal allowed) }\end{array}$ & $\begin{array}{l}2 \\
\text { (17\% of cases with } \\
\text { negative comment } \\
\text { where appeal is } \\
\text { allowed) } \\
\text { ( } 22 \% \text { of cases with } \\
\text { negative comment in } \\
\text { majority reasons \& } \\
\text { appeal allowed) }\end{array}$ & $\begin{array}{l}6 \\
\text { ( } 50 \% \text { of cases with } \\
\text { negative comment } \\
\text { where appeal is } \\
\text { allowed) } \\
\text { (67\% of cases with } \\
\text { negative comment in } \\
\text { majority reasons \& } \\
\text { appeal allowed) }\end{array}$ \\
\hline $\begin{array}{l}\text { Comment in } \\
\text { Majority Reasons } \\
\text { \& Appeal } \\
\text { Dismissed }\end{array}$ & $\begin{array}{l}4 \\
\text { (44\% of negative } \\
\text { comment cases } \\
\text { where appeal is } \\
\text { dismissed) }\end{array}$ & $\begin{array}{l}1 \\
\text { ( } 11 \% \text { of negative } \\
\text { comment cases } \\
\text { where appeal is } \\
\text { dismissed) } \\
\text { ( } 25 \% \text { of cases with } \\
\text { negative comment in } \\
\text { majority reasons \& } \\
\text { appeal dismissed) }\end{array}$ & $\begin{array}{l}1 \\
\text { ( } 11 \% \text { of negative } \\
\text { comment cases } \\
\text { where appeal is } \\
\text { dismissed) } \\
\text { ( } 25 \% \text { of cases with } \\
\text { negative comment in } \\
\text { majority reasons \& } \\
\text { appeal dismissed) }\end{array}$ & $\begin{array}{l}2 \\
(22 \% \text { of negative } \\
\text { comınent cases } \\
\text { where appeal is } \\
\text { dismissed) } \\
\text { ( } 50 \% \text { of cases with } \\
\text { negative comment in } \\
\text { majority reasons \& } \\
\text { appeal dismissed) }\end{array}$ \\
\hline
\end{tabular}


FIGURE 6: NEgATIVE COMMENTARY IN DISSENTING REASONS

\begin{tabular}{|c|c|c|c|c|}
\hline & All Issues & Charter Cases & $\begin{array}{c}\text { Non-Charter } \\
\text { Constitutional Law } \\
\text { Cases }\end{array}$ & "Other" Cases \\
\hline $\begin{array}{l}\text { Comment In } \\
\text { Dissenting Reasons }\end{array}$ & $8(38 \%)$ & $1(5 \%)$ & $2(9 \%)$ & $5(24 \%)$ \\
\hline $\begin{array}{l}\% \text { of Cases with } \\
\text { Negative } \\
\text { Commentary In } \\
\text { Dissenting Reasons }\end{array}$ & $100 \%$ & $13 \%$ & $25 \%$ & $62 \%$ \\
\hline $\begin{array}{l}\text { Comment in } \\
\text { Dissenting Reasons } \\
\text { \& Appeal Allowed }\end{array}$ & $\begin{array}{l}3 \\
\text { (25\% of cases with } \\
\text { negative comment } \\
\text { where appeal is } \\
\text { allowed) }\end{array}$ & $\mathbf{0}$ & 0 & $\begin{array}{l}3 \\
\text { (25\% of cases with } \\
\text { negative comment } \\
\text { where appeal is } \\
\text { allowed) } \\
\text { (100\% of cases with } \\
\text { negative comment in } \\
\text { dissenting reasons \& } \\
\text { appeal allowed) }\end{array}$ \\
\hline $\begin{array}{l}\text { Comment in } \\
\text { Dissenting Reasons } \\
\text { \& Appeal } \\
\text { Dismissed }\end{array}$ & $\begin{array}{l}5 \\
\text { ( } 56 \% \text { of negative } \\
\text { comment cases } \\
\text { where appeal is } \\
\text { distnissed) }\end{array}$ & $\begin{array}{l}\text { I } \\
\text { (12\% of negative } \\
\text { comment cases } \\
\text { where appeal is } \\
\text { dismissed) } \\
\text { ( } 20 \% \text { of cases with } \\
\text { negative comment in } \\
\text { dissenting reasons \& } \\
\text { appeal dismissed) }\end{array}$ & $\begin{array}{l}2 \\
\text { (22\% of negative } \\
\text { comment cases } \\
\text { where appeal is } \\
\text { dismissed) } \\
\text { (40\% of cases with } \\
\text { negative coinment in } \\
\text { dissenting reasons \& } \\
\text { appeal dismissed) }\end{array}$ & $\begin{array}{l}2 \\
\text { (22\% of ncgative } \\
\text { comment cases } \\
\text { where appeal is } \\
\text { dismissed) } \\
\text { (40\% of cases with } \\
\text { negative comment in } \\
\text { dissenting reasons \& } \\
\text { appeal dismissed) }\end{array}$ \\
\hline
\end{tabular}

Looking at the data on a yearly basis, Figure 7 indicates that public law matters have been pursued from the Alberta Court of Appeal to the Supreme Court of Canada in every year from 1982 to 2000. Nevertheless, in 1985, 1987, 1988, 1990, 1994, 1996, and 1997 the Supreme Court did not overtly criticize the Alberta Court despite the fact that the highest number of public law appeals occurred in several of those years (namely, 1985, 1989, and 1990). The highest concentration of public law cases including negative commentary occurred in 1982,1983,1989,1992,1998, 1999, and 2000. However, in several of these years (most notably 1998, 1999, and 2000) the least number of public law cases were appealed from the Alberta Court of Appeal. Thus the annual data does not reveal any meaningful patterns or trends with respect to the issues appealed in any particular year or set of years. 


\section{Figure 7: Negative CoMment Cases Per Year}

\begin{tabular}{|c|c|c|c|c|}
\hline Year & Total \# of Public Law Cases & Total \# of Negative Comment Cases & Percent & Issue \\
\hline 1982 & 5 & 2 & $40 \%$ & $\begin{array}{l}\text { I NCC } \\
\text { I Other }\end{array}$ \\
\hline 1983 & 5 & 3 & $60 \%$ & $\begin{array}{l}2 \mathrm{NCC} \\
1 \text { Other }\end{array}$ \\
\hline 1984 & 7 & 1 & $14 \%$ & I Other \\
\hline 1985 & 10 & $\mathbf{0}$ & 0 & 0 \\
\hline 1986 & 5 & 1 & $20 \%$ & I C \\
\hline 1987 & 4 & 0 & 0 & 0 \\
\hline 1988 & 4 & 0 & 0 & 0 \\
\hline 1989 & 14 & 4 & $29 \%$ & $\begin{array}{l}1 \mathrm{C} \\
3 \text { Other }\end{array}$ \\
\hline 1990 & 15 & 0 & 0 & 0 \\
\hline 1991 & 6 & 1 & $17 \%$ & I NCC \\
\hline 1992 & 9 & 3 & $33 \%$ & 3 Other \\
\hline 1993 & 13 & 1 & $8 \%$ & I Other \\
\hline 1994 & 7 & 0 & $\mathbf{0}$ & $\mathbf{0}$ \\
\hline 1995 & 5 & 1 & $20 \%$ & I Other \\
\hline 1996 & 6 & 0 & 0 & 0 \\
\hline 1997 & 5 & 0 & 0 & 0 \\
\hline 1998 & 6 & 2 & $33 \%$ & $\begin{array}{l}1 \text { Other } \\
\text { I C }\end{array}$ \\
\hline 1999 & 2 & 1 & $50 \%$ & I Other \\
\hline 2000 & 4 & 1 & $25 \%$ & I NCC \\
\hline
\end{tabular}

Finally, Figure 8 shows that some justices have been more prone to making negative commentary than others. Of the 21 public law decisions containing negative commentary 5 (24 percent) were written by Justice L'Heureux-Dubé ( 3 in majority reasons and 2 in dissent). Justice Dickson and Justice Laskin each wrote 3 decisions ( 14 percent) containing negative commentary ( 2 majority and 1 dissent each). Justices Wilson, Cory, and Lamer each wrote 2 ( 9 percent) such decisions ( 2 dissents for Justice Wilson and 1 majority and 1 dissent each for Justices Cory and Lamer). Justices La Forest, Sopinka, and Gonthier each wrote 1 (5 percent) negative commentary judgment (all majority reasons). 


\section{Figure 8: Negative COMMENT CASES ACCORding to JUDGE WRITING THE COMMENT}

\begin{tabular}{|l|l|l|l|l|l|l|}
\hline \multicolumn{1}{|c|}{ Judge } & $\begin{array}{c}\text { Total \# of } \\
\text { Public Law } \\
\text { Case } \\
\text { Decisions } \\
\text { Written }\end{array}$ & $\begin{array}{c}\text { \# of Public } \\
\text { Law Case } \\
\text { Majority } \\
\text { Decisions }\end{array}$ & $\begin{array}{c}\text { \# of Public } \\
\text { Law Case } \\
\text { Dissents }\end{array}$ & $\begin{array}{c}\text { \# of Public } \\
\text { Law Charter } \\
\text { Decisions }\end{array}$ & $\begin{array}{l}\text { \# of Public } \\
\text { Law NCC }\end{array}$ & $\begin{array}{c}\text { \# of Public } \\
\text { Law } \\
\text { uOther" } \\
\text { Decisions }\end{array}$ \\
\hline L'Heureux-Dubė & $5(24 \%)$ & 3 & 2 & 0 & 0 & 5 \\
\hline Dickson & $3(14 \%)$ & 2 & 1 & 0 & 0 & 3 \\
\hline Laskin & $3(14 \%)$ & 2 & 1 & 0 & 3 & 0 \\
\hline Cory & $2(9.33 \%)$ & 1 & 1 & 1 & 1 & 0 \\
\hline Wilson & $2(9.33 \%)$ & 0 & 2 & 1 & 0 & 1 \\
\hline Lamer & $2(9.33 \%)$ & 1 & 1 & 0 & 0 & 2 \\
\hline La Forest & $1(5 \%)$ & 1 & 0 & 1 & 0 & 0 \\
\hline Sopinka & $1(5 \%)$ & 1 & 0 & 0 & 0 & 1 \\
\hline Gonthier & $1(5 \%)$ & 1 & 0 & 0 & 0 & 1 \\
\hline by the Court & $1(5 \%)$ & 1 & 0 & 0 & 1 & 0 \\
\hline
\end{tabular}

Note: Iacobucci concurred with Cory in writing I majority decision on a ('hurter matter (Vriend).

Figure 9 indicates that some Alberta Court of Appeal justices were more likely than others to have their decisions expressly criticized by the Supreme Court of Canada. Of the 21 cases in which the Supreme Court commented negatively on the reasoning of the Alberta Court of Appeal, 4 criticized the reasoning of Justice McClung, while 3 criticized the analysis of Justice Kerans. Accordingly, the Supreme Court overtly criticized the reasoning of Justice McClung and Justice Kerans in one-third of all the negative commentary cases. The decisions of Justices Côté, Conrad, Laycraft, and Harradence also appear to have attracted a fair amount of criticism from the Supreme Court, with 2 public law decisions from each of these Justices being the subject of the Supreme Court's criticism. One public law decision by each of Justices Lieberman, Prowse, Dea, and Fraser was overtly criticized by the Supreme Court.

With only two exceptions - Justices Harradence and McClung - where a Court of Appeal justice was overtly criticized in more than one case, a different justice of the Supreme Court of Canada delivered the criticism. Justice Harradence's reasoning is twice criticized by Justice Dickson. In 3 of the 4 cases Justice McClung's analysis was criticized by Justice L'Heureux-Dubé. With regard to the legal issues involved in these cases, each of the "repeat" criticisms involved matters that fall into the "other" category. Justice Dickson's criticism of Justice Harradence's judgments both related to criminal law 
questions. ${ }^{24}$ One of Justice L'Heureux-Dubé's criticisms of Justice McClung's reasoning concerned the interpretation of the Young Offenders $A c t,{ }^{25}$ and the remaining two concerned the interpretation of the sexual assault provisions of the Criminal Code. ${ }^{26}$

\section{Figure 9: WhOSE COURT OF APPEAL DECISION IS THE SUBJECT OF THE SUPREME COURT'S NEGATIVE COMMENTARY}

\begin{tabular}{|c|c|c|c|}
\hline Judge & $\begin{array}{l}\text { \# of Public Law Decisions } \\
\text { Criticized by the SCC }\end{array}$ & $\begin{array}{c}\text { Name of Case(s) Where Decision is } \\
\text { Criticized }\end{array}$ & $\begin{array}{l}\text { Issue Raised by } \\
\text { the Case }\end{array}$ \\
\hline McClung & 4 & $\begin{array}{l}\text { R. v. Il:I. } \\
\text { R. v. I'urk } \\
\text { R. v. Vriemd } \\
\text { R. v. I:urmichuk }\end{array}$ & $\begin{array}{l}\text { Other } \\
\text { Other } \\
\text { C } \\
\text { Other }\end{array}$ \\
\hline Kerans & 3 & $\begin{array}{l}\text { R. v. Wessendorm } \\
\text { Black v. law Society of Alherra } \\
\text { R. v. I)AZ }\end{array}$ & $\begin{array}{l}\text { NCC } \\
\text { C } \\
\text { Other }\end{array}$ \\
\hline Côté & 2 & $\begin{array}{l}\text { R. v. Milme } \\
\text { R. v. } A W I:\end{array}$ & $\begin{array}{l}\text { Other } \\
\text { Other }\end{array}$ \\
\hline Conrad & 2 & $\begin{array}{l}\text { R. v. Al Klippert lind. } \\
\text { Re lineums } A C l\end{array}$ & $\begin{array}{l}\text { Other } \\
\text { NCC }\end{array}$ \\
\hline Laycraft & 2 & $\begin{array}{l}\text { R. v. SHM } \\
\text { Soldicr Selllement v. Sinider Listume }\end{array}$ & $\begin{array}{l}\text { Other } \\
\text { NCC }\end{array}$ \\
\hline Harradence & 2 & $\begin{array}{l}\text { R. v. Ifuid } \\
\text { Re. Indicuture } A C t\end{array}$ & $\begin{array}{l}\text { Other } \\
\text { Other }\end{array}$ \\
\hline Lieberman & 1 & R. v. Jomes & c \\
\hline Prowse & 1 & ('NI v. Alherra & $\mathrm{NCC}$ \\
\hline Dea & 1 & R. v. l.eaney & Other \\
\hline Fraser & 1 & R. v. Morin & Other \\
\hline - The Court & 2 & $\begin{array}{l}\text { R. v. (ice } \\
\text { Re lropesed liedenel Far }\end{array}$ & $\begin{array}{l}\text { Other } \\
\text { NCC }\end{array}$ \\
\hline
\end{tabular}

- Note: "The Court" designates either a decision written by the full court or a case where several justices wrote separate but concurring reasons and where the SCC criticized the reasoning of the court as a whole without specifying a particular judgment. Judicature Act, [1984] 2 S.C.R. 697, rev'g (1983), 50 A.R. I [hereinafter Re Jidicature Act]. R.S.C. 1985, c. Y-I, see R. v. L.(J.E.), [1989] 2 S.C.R. 510, affg [1987] A.J. No. I124, online: QL, (AJ) [hereinafter $J E L]$.

26. R.S.C. 1985, c. C-46, see R. v. Park. [1995] 2 S.C.R. 836, rev'g (1993), 145 A.R. 207 [hereinafter Park] and Ewanchuk, supra note I. 


\section{BEyond the Numbers: THE SUbSTANCE OF THE SUPREME COURT'S NEGATIVE COMMENTARY}

\section{A. Classifying the negative Commentary Cases}

Thus far this article has primarily summarized the empirical data regarding the public law cases in which the Supreme Court has overtly criticized the reasoning of the Alberta Court of Appeal. However, as stated at the outset, in order to determine whether and to what extent the Supreme Court of Canada and the Alberta Court of Appeal fundamentally diverge on public law matters, it is necessary to look beyond the numbers and to examine the substance of the Supreme Court's negative commentary. To facilitate this substantive analysis, the public law cases containing negative commentary have been classified in three ways. First, as in the preceding sections of this article, the cases are classified according to the topic or content of the criticism: Charter matters, non-Charter constitutional matters ("NCC" in figures), and "other" matters. Second, the cases are classified according to the outcome of the appeal and the source of the negative commentary. The resulting categories within this class are: allowed appeal with negative commentary in majority reasons ("AA/MR"); allowed appeal with negative commentary in dissenting reasons ("AA/DR"); dismissed appeal with negative commentary in majority reasons ("AD/MR"); and dismissed appeal with negative commentary in dissenting reasons ("AD/DR"). Third, the comments are classified according to the tone or demeanour of the Court's criticism: specifically, whether the criticism suggests that the Court of Appeal made a legal error ("LE"), a serious legal error ("SLE"), or a flagrant legal error ("FLE"). Figure 10 lists all of the cases containing negative commentary and identifies how each case has been categorized within each of the three areas of classification.

Figure 10: Classification of CaSes

\begin{tabular}{|c|c|c|c|}
\hline Case Name & Case Topic & Result and Reasons & Tone of Comment \\
\hline R. v. Fuid & Other & AA/MR & LE \\
\hline R. v. Morin & Other & AA/MR & LE \\
\hline R. v. Milne & Other & AA/MR & LE \\
\hline R. v. Al Klipper Isd. & Other & AA/MR & LE \\
\hline R. v. Vriend & (harter & AA/MR & LE \\
\hline R. v. Westendorp & NCC & AA/MR & SLE \\
\hline R. v. Park & Other & AA/MR & SLE \\
\hline CNT v. Alberru & $\mathrm{NCC}$ & AA/MR & FLE \\
\hline R. v. Ewanchuk & Other & AA/MR & FLE \\
\hline R. v. Leamey & Other & AADR & LE \\
\hline R. v. $A W I:$ & Other & AA/DR & LE \\
\hline Re Judicanure ACt & Other & AANDR & SLE \\
\hline
\end{tabular}




\begin{tabular}{|c|c|c|c|}
\hline Case Name & Case Topic & Result and Reasons & Tone of Comment \\
\hline R. v. Gee & Other & AD/MR & LE \\
\hline Black v. Law Siciely of Alherta & Charrer & AD/MR & LE \\
\hline R. v. $D A Z$ & Olher & $\mathrm{AD} / \mathrm{MR}$ & LE \\
\hline Re Fireanms $A C l$ & NCC & $\mathrm{AD} / \mathrm{MR}$ & LE \\
\hline R. v. Jones & ('harrer & $\mathrm{AD} / \mathrm{DR}$ & LE \\
\hline Soldier Selllemem v. Sinider Esstute & NCC & AD/DR & LE \\
\hline $\begin{array}{l}\text { Re Proposed Federal Tax on lixported } \\
\text { Natural Gas }\end{array}$ & NCC & $\mathrm{AD} / \mathrm{DR}$ & SLE \\
\hline R. v. SHM & Other & AD/DR & SLE \\
\hline R. v. JEL & Other & $\mathrm{AD} / \mathrm{DR}$ & FLE \\
\hline
\end{tabular}

\section{B. MORE ON The ThiRd Class: TONe Of The Negative Comments}

The third area of classification - that is, the categorization of the Court's criticism according to tone - is necessarily the most subjective of the three classes. It is reasonable to assume, however, that the Supreme Court's attitude in providing negative commentary is an important indicator of how strongly the Supreme Court disagreed with the Alberta Court's reasoning and of how fundamental the disagreement between the courts was. Accepting this premise, categorizing the Court's negative commentary according to the demeanour of the criticism is essential to this article's analysis of the divergence in public law perspectives of the two courts.

Cases that fall into the legal error ("LE") category are those in which the Supreme Court's criticism of the Alberta Court of Appeal was limited to an express recognition that the lower court misunderstood the law or misapplied a legal principle. The negative commentary in these cases has an overall respectful tone and only indicates that the reasoning employed by the Court of Appeal was analytically flawed. The Supreme Court's negative comments in Faid $^{27}$ and Vriend $^{28}$ are paradigms of the type of criticisms that fall into this category.

In Faid the Court of Appeal set aside the murder conviction of the accused, Donald Faid, on the grounds that the jury charge at the accused's trial was inadequate. The Court of Appeal concluded that a jury charge under the self-defence provision of s. 34(2)of the Criminal Code should include a charge on the possibility of convicting for manslaughter if the accused had used excessive force in defending himself against an unprovoked 
assault. ${ }^{29}$ Ultimately, the Supreme Court of Canada restored Faid's conviction, holding that the jury had found the requisite intent for murder and that the original trial judge's charge to the jury was not in error. In considering the proper interpretation of s. 34(2) of the Criminal Code, Justice Dickson, writing for a unanimous Court, made the following comments regarding the approach of the Alberta Court of Appeal:

It was. as I have said, the view of the Court of Appeal that a manslaughter verdict was open in circumstances where an accused used excessive force in self-defence.... The "half-way house" shelter of manslaughter was available to him.

The position of the Alberta Court of Appeal that there is a "half-way" house outside s. 34 of the Code is, in my view, inapplicable to the Canadian codified system of criminal law, it lacks any recognizable basis in principle, would require prolix and complicated jury charges and would encourage juries to reach compromise verdicts to the prejudice of either the accused or the Crown.

With respect, 1 conclude that the Court of Appeal of Alberta erred in finding misdirection in the failure of the judge at trial to instruct the jury that they could bring in a verdict of manslaughter if they found that $\mathrm{s} .34$ was not available to the accused by reason of excessive use of force. ${ }^{\text {." }}$

Thus while the Supreme Court of Canada clearly disagreed with the Court of Appeal's application of the law, the Supreme Court was respectful in expressing its view that the Court of Appeal misapplied and misinterpreted the law.

In Vriend the Supreme Court of Canada was similarly cautious and respectful in rejecting the Alberta Court's interpretation of the law, although the divergence of opinion and result between the two courts in this case was dramatic. The Vriend case concerned a complaint brought to the Alberta Human Rights Commission by Delwin Vriend, a homosexual teacher who had been fired from his teaching position at a Christian college because of his sexual orientation. The main question in Vriend was whether Alberta's Individual Rights Protection Act ${ }^{31}$ violated s. 15 of the Charter by failing to provide protection against discrimination on the basis of sexual orientation. A related issue was whether such protection should be "read in" to the statute in the event that a Charter violation was found. A majority of the Alberta Court of Appeal ${ }^{32}$ held that the Charter could not be violated by a legislative omission and that, in any event, the legislation in

24 The Criminal Code, supra note 26 at s. 34(2) requires that an accused, in order to rely upon this provision, use no more force than is necessary "to preserve himself from death or grievous bodily harm." An accused individual who uses excessive force in repelling an unprovoked assault has not complied with all of the requirements of the section. The issue in Faid was how to properly dispose of a case in which the accused had complied with all of the requirements of s. 34(2) but had used excessive force.

4i) Supra note 24 at $270-71$.

"R.S.A. 1980, c. 1-2. This statute has been repealed and its provisions are now subsumed by the Human Rights Citizenship and Multiculturalism ACt, R.S.A. 1980, c. H-I1.7.

"2 Separate majority reasons were written by Justices McClung and O'Leary, with the dissenting opinion being written by Justice Hunt. 
question did not create an inequality between homosexuals and heterosexuals because the legislation did not protect either group from discrimination based on sexual orientation. The Supreme Court of Canada unanimously overturned the Court of Appeal's decision on the main question, holding that the Charter can apply to legislative omissions and that the failure of the Individual Rights Protection Act to prohibit discrimination on the basis of sexual orientation had a discriminatory effect on homosexuals, a socially vulnerable group. Seven of the eight Supreme Court Justices also held that sexual orientation should be read in to the legislation. Only Justice Major determined that the appropriate remedy was a suspended declaration of invalidity of the entire $\mathrm{Act}$.

While fundamentally disagreeing with the position taken by the Court of Appeal, the Supreme Court of Canada was remarkably reserved in its negative commentary. For example, in their reasons for judgment Justices Cory and lacobucci characterized Justice McClung's opinion of the law as "mistaken"33 and indicated that there was "no legal basis" $^{34}$ to support Justice McClung's distinction between the Charter's application to legislative action and inaction. Further, Justices Cory and lacobucci stated that they could not agree ${ }^{35}$ with Justice Hunt's analysis regarding the appropriateness of the "reading in" remedy. In a separate judgment, Justice L'Heureux-Dubé presented a s. 15 Charter analysis that completely diverged from the Court of Appeal's approach. Nevertheless, Justice L'Heureux-Dubé avoided making any direct negative comments about the Court of Appeal's reasoning.

Cases that fall into the serious legal error ("SLE") category are those in which the Supreme Court's negative commentary was slightly more pointed, identifying a gross or severe misunderstanding or misapplication of the law by the Alberta Court of Appeal. While falling short of accusing the Court of Appeal of committing an intentional error of law, these criticisms are strongly worded and suggest that the Alberta Court of Appeal has been unreasonable in its interpretation of the law. In reading these negative comments, one can imagine the Supreme Court Justices shaking their heads in disbelief at the Alberta Court's position. Prime examples of comments that fall into this category can be found in Westendorp ${ }^{36}$ and Park. ${ }^{37}$

In Westendorp the accused was charged with being on a street for the purpose of prostitution, contrary to a City of Calgary bylaw. In her defence, the accused argued that the bylaw was invalid because it constituted an unconstitutional invasion of the federal criminal law power ${ }^{38}$ by the province or its municipal delegate. The Alberta Court of Appeal rejected this defence and found that the bylaw was designed to address public nuisances and, therefore, fell within the province's power over matters of local and private nature. ${ }^{39}$ The Supreme Court of Canada disagreed and held that the pith and substance of the bylaw was to punish prostitution. Therefore, the bylaw was an unconstitutional

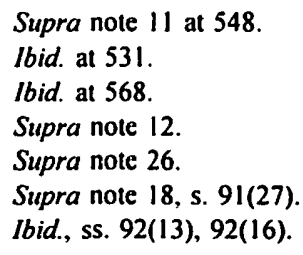


encroachment into the federal government's exclusive jurisdiction over criminal law. In his judgment Chief Justice Laskin described the Court of Appeal's characterization of the legislation as public nuisance prevention as "baffling" and "doubly baffling." 40

In the Park case a majority of the Court of Appeal reversed the accused's sexual assault conviction on the grounds that the trial judge had failed to charge the jury on the defence of mistake of fact regarding consent. For the Court of Appeal, Justices McClung and Stratton held that the defence should have been put to the jury because the background facts regarding the relationship between the accused and the complainant gave an air of reality to the defence. The Supreme Court of Canada disagreed and restored the conviction. In her judgment Justice L'Heureux-Dubé offered the following comments regarding Justice McClung's analysis:

Evidence going to an ancillary issue or failing to address a clear and undisputed logical inconsistency in an accused's claim to the honest mistake defence, then, will not, itself, be sufficient to lend that defence an air of reality. Although this conclusion seems obvious, it is apparently not always being followed, judging by the type of evidence deemed at times to be supportive of the defence. With all due respect to McClung J.A., the present case is no exception.

The factors listed by McClung J.A. as lending an air of reality to that defence ... are all only capable, if anything, of supporting a belief on the part of the respondent that the complainant would consent.... None of these factors address or relate in any realistic way to the events that actually took place at the time of the alleged assault."

These comments, like those in the Westendorp case, suggest that the Court of Appeal's conclusions were illogical or ill founded.

Finally, cases that fall into the flagrant legal error ("FLE") category are those in which the tone of the Supreme Court's negative commentary implied that the Court of Appeal flagrantly disregarded established legal principles in order to attain a desired result. The nature of these criticisms is more than merely pointed - the comments are disapproving of the lower court's approach and suggest that the Court of Appeal intentionally or deliberately misapplied the law. Here, one might imagine the Supreme Court Justices shaking their heads and tsking while writing their critique. The most obvious example of negative comments falling within this category are those provided by Justice L'HeureuxDubé in Ewanchuk. ${ }^{42}$ Another example of such commentary is provided in Canada (A.G.) v. Canadian National Transportation. ${ }^{43}$

In Ewanchuk the accused was charged with sexual assault. The complainant said "no" to each sexual advance by the accused but remained physically passive during the assault. The question was whether a defence of implied consent was available to the accused and 
whether this defence had been proven on the facts. The trial judge dismissed the charge on the ground that the Crown had not disproved implied consent and, therefore, had failed in its burden to prove that the accused had knowledge of the complainant's lack of consent. A majority of the Court of Appeal upheld the trial judge's finding. In three separate judgments the Supreme Court of Canada unanimously disagreed with the Court of Appeal's finding and entered a guilty verdict. In her reasons for judgment Justice L'Heureux-Dubé extensively criticized the approach taken by Justice McClung. For instance, she stated that

"McClung J.A. [does] not make the basic distinction that consent is a matter of the state of mind of the
complainant and belief in consent is, subject to s. 273.2 of the Criminal Code, a matter of the state of
mind of the accused." ... This error does not derive from the findings of fact but from mythical
assumptions that when a woman says "no" she is really saying "yes". "try again", or "persuade me."

McClung J.A. compounded the error made by the trial judge.... He stated ... "it must be pointed out that the complainant did not present herself to Ewanchuk or enter his trailer in a bonnet and crinolines".... These comments made by an appellate judge help reinforce the myth that under such circumstances, either the complainant is less worthy of belief, she invited the sexual assault, or her sexual experience signals probable consent.

The expressions used by McClung J.A. to describe the accused's sexual assault ... are plainly inappropriate in the context as they minimize the importance of the accused's conduct and the reality of sexual aggression against women. ${ }^{+}$

In the CNT case the Supreme Court of Canada reviewed the Court of Appeal's finding that the province had exclusive power to prosecute under the federal Combines Investigation Act. ${ }^{45}$ The Supreme Court unanimously overturned the Court of Appeal ruling and held that federal authorities can prosecute any offence that arises from the violation of a federal statute, even one created under the criminal law power. Writing one of the three concurring judgments, Chief Justice Laskin made the following comment regarding the Court of Appeal's reasoning: "What has dismayed me in both the majority and minority reasons is the rather 'heavy going' that is exhibited in order to preserve provincial prosecutorial authority in respect of the federal criminal law."46

Supra note 1 at 372-74; * Justice L'Heureux-Dubé quoting with approval: Professor D. Stuart, Annotation in R. v. Ewanchuk (1998), 13 C.R. (5th) 330 at 330. 1985, c. C-34. 


\section{THE RELATIONSHIP BetWEen THE RESILt OF THE APPEAL AND THE TONE OF THE NEGATIVE COMMENT}

\section{Figure 11: SUMMARY OF DATA RE NEGATIVE COMMENTS ACCORDING TO RESULT OF APPEAL \& TONE OF COMMENT}

\begin{tabular}{|c|c|c|c|}
\hline & LE & SLE & FLE \\
\hline Appeal Allowed & $\begin{array}{l}7 \text { Cases: } \\
5 \text { Comments in MR } \\
2 \text { Comments in DR }\end{array}$ & $\begin{array}{l}3 \text { Cases: } \\
2 \text { Comments in MR } \\
1 \text { Coinment in DR }\end{array}$ & $\begin{array}{l}2 \text { Cases: } \\
2 \text { Comınents in MR }\end{array}$ \\
\hline Appeal Dismissed & $\begin{array}{l}6 \text { Cases: } \\
4 \text { Comments in MR } \\
2 \text { Comments in DR }\end{array}$ & $\begin{array}{l}2 \text { Cases: } \\
2 \text { Comments in DR }\end{array}$ & $\begin{array}{l}1 \text { Case: } \\
1 \text { Coininent in DR }\end{array}$ \\
\hline Totals & $\begin{array}{l}13 \text { Cases: } \\
9 \text { Comments in MR } \\
4 \text { Comments in DR }\end{array}$ & $\begin{array}{l}5 \text { Cases: } \\
2 \text { Coinınents in MR } \\
3 \text { Comments in DR }\end{array}$ & $\begin{array}{l}3 \text { Cases: } \\
2 \text { Coimments in MR } \\
1 \text { Comment in DR }\end{array}$ \\
\hline
\end{tabular}

Figure $1 /$ summarizes the data regarding the negative comment cases according to the result of the appeal and the tone of the Supreme Court's criticism. Regardless of whether the appeal was allowed or dismissed, negative comments that fall into the LE category occur more than twice as often in the majority as in the dissenting reasons. This ratio holds true for comments falling in the SLE category where the appeal was allowed. All of the SLE negative comments in dismissed appeals appear in the dissenting reasons. Negative commentary that falls into the FLE classification is found in the majority reasons in both cases where the appeal was allowed and in the dissenting reasons in the one case where the appeal was dismissed.

\section{THE RELATIONSHIP BETWEEN THE TOPIC CONSIDERED AND THE TONE OF THE NEGATIVE COMMENT}

\section{FIGURE 12: SUMmARY OF DATA RE NEGATIVE COMMENTS ACCORDING TO TOPIC CONSIDERED \& TONE OF COMMENT}

\begin{tabular}{|c|c|c|c|}
\hline & LE & SLE & FLE \\
\hline Charter & $\begin{array}{l}3 \text { Cases: } \\
1 \text { AA/MR } \\
1 \text { AD/MR } \\
1 \text { AD/DR }\end{array}$ & 0 Cases & 0 Cases \\
\hline $\begin{array}{l}\text { Non-Charter } \\
\text { Constitutional Law }\end{array}$ & $\begin{array}{l}2 \text { Cases: } \\
\text { I AD/MR } \\
\text { I AD/DR }\end{array}$ & $\begin{array}{l}2 \text { Cases: } \\
\text { I AA/MR } \\
\text { I AD/DR }\end{array}$ & $\begin{array}{l}\text { I Case: } \\
\text { I AA/MR }\end{array}$ \\
\hline Other & $\begin{array}{l}8 \text { Cases: } \\
4 \text { AA/MR } \\
4 \text { AD/DR }\end{array}$ & $\begin{array}{l}3 \text { Cases: } \\
\text { I AAMMR } \\
1 \text { AA/DR } \\
\text { I AD/DR }\end{array}$ & $\begin{array}{l}2 \text { Cases: } \\
\text { I AA/MR } \\
\text { IAD/MR }\end{array}$ \\
\hline
\end{tabular}

Figure 12 summarizes the data regarding the Supreme Court's negative commentary according to the topic being considered and the tone of the comment. Figure 12 also 
identifies the result and source of each negative commentary. With respect to Charter cases, Figure 12 indicates that all of the Supreme Court's negative commentary falls within the LE category. The criticisms fall into this single category despite the fact that each criticism arises in a different circumstance and deals with a different Charter provision. In $V_{r i e n d} d^{47}$ the Supreme Court considered the application of ss. 15 and 24 of the Charter, and the Court's negative commentary appeared in the majority judgment on the successful appeal. In Black v. Law Society of Alberta ${ }^{48}$ the Court analyzed s. 6 of the Charter, and the negative commentary appeared in the majority judgment in an unsuccessful appeal. Finally, in $R$. v. Jones ${ }^{49}$ the Court considered ss. 2(a), 7, and 24 of the Charter, and the negative commentary appeared in the dissenting reasons of the dismissed appeal.

The common thread among the Charter cases is that negative commentary in each case involved the Supreme Court criticizing the Alberta Court of Appeal's narrow or restrictive interpretation and application of the Charter. ${ }^{50}$ Thus the majority of the negative commentary of the Supreme Court in Charter cases suggests that, from 1982 - 2000, the Supreme Court's approach to Charter issues was more liberal than that of the Alberta Court of Appeal. The Supreme Court displayed a greater willingness to find that the Charter applied and that Charter remedies were available.

As illustrated in Figure 12, of the five non-Charter constitutional cases three included negative commentary in the majority reasons, ${ }^{51}$ two of which resulted in successful appeals, ${ }^{52}$ and one in a failed appeal. ${ }^{53}$ The comment in the latter case addressed the findings of the dissenting judges at the Court of Appeal level. In the two cases having negative commentary in the dissenting reasons the appeal was dismissed. ${ }^{54}$ In one of these cases, ${ }^{55}$ however, the dissent's negative commentary related to a finding of the Alberta Court of Appeal that was not ultimately supported by the majority of the Supreme Court. In other words, a majority of the Supreme Court of Canada dismissed the appeal for reasons other than those offered by the Court of Appeal. In the second case ${ }^{56}$ the negative commentary criticized the very reasoning that was supported by a majority of the Supreme Court. That is, the negative comments would not be endorsed by most of the Supreme Court.

Supra note 11.

[1989] I S.C.R. 591, aff g (1986), 68 A.R. 259 [hereinafter Black].

[1986] 2 S.C.R. 284, affg (1984), 57 A.R. 266 [hereinafter Jones].

This is so even in the Black and Jones cases, where the appeal was ultimately dismissed. In these two cases the Supreme Court's overt criticism did not locus on the ratio of the lower court but rather on a side issue regarding Charter interpretation.

See Westendorp, supra note 12; CNT, supra note 43; and Reference Re Firearms Act. [2000] I S.C.R. 783, affg (1998), 164 D.L.R. (4th) 513 [hereinafter Re Firearms].

Ibid., see Westendorp and CNT.

See Re Firearms, supra note 51.

See Canada (Director of Soldier Settlement) v. Snider Estate, [1991] 2 S.C.R. 48I, aff'g (1988), 88 A.R. 385 [hereinafter Soldier Settlement] and Reference Re Proposed Federal Tax on Exported Natural Gas, [1982] I S.C.R. 1004, afTg (1981), 28 A.R. II [hereinafter Re Proposed Federal Tax]. See Soldier Settlement, supra note 54 at 511 .

See Re Proposed Federal Tax, supra note 54 at 1026-29. 
Only two of the criticisms in the non-Charter constitutional law cases are characterized as identifying an error of law. ${ }^{57}$ Two others are characterized as pointing out serious errors of law, ${ }^{58}$ and one falls into the category of identifying a flagrant error of law. ${ }^{59}$ In each case, regardless of tone, the Supreme Court's criticism was directed at the apparent willingness of the Court of Appeal (or certain judges of the Court of Appeal) to interpret provincial powers too broadly. This subject of criticism appears consistent regardless of whether the case at bar involved an interpretation of federal or provincial legislation. These cases suggest that the Supreme Court favoured the broad interpretation of federal powers and the narrow interpretation of provincial powers, while the Alberta Court of Appeal took the opposite approach.

The thirteen cases which fall into the class of "other" topics can be subdivided into the following subject areas:

(i) interpretation of Criminal Code provisions (other than sexual assault);

(ii) interpretation of sexual assault provisions;

(iii) interpretation of young offenders legislation; and

(iv) interpretation of trial evidence or appeal procedures.

In the three cases dealing with the interpretation of Criminal Code provisions ${ }^{60}$ all the criticisms appeared in the majority judgments, two in cases where the appeal was allowed, ${ }^{61}$ and one where the appeal was dismissed. ${ }^{62}$ In tone, all the comments identified simple misunderstandings of law. Also, in each case, the Supreme Court criticized the Alberta Court of Appeal's allowance of defences that the Supreme Court did not believe were warranted or justified by the Criminal Code provisions. These cases suggest that the Supreme Court was stricter than the Alberta Court of Appeal in applying the Criminal Code provisions to adult offenders.

In the two cases dealing with sexual assault ${ }^{63}$ the Court was required to interpret the defence of consent. The criticisms in both of these cases appeared in majority judgments where the appeal was allowed. Further, in both cases the criticisms were very strongly worded, importing to the Alberta Court of Appeal either a serious or a flagrant legal error. In both cases the Supreme Court took a narrower approach to the nature of the consent defence, suggesting that the Alberta Court of Appeal made this defence too easy for the accused to establish. Where the Alberta Court of Appeal looked to several outside factors to establish consent, the Supreme Court of Canada dismissed many of these factors as irrelevant. The cases, therefore, indicate that the Supreme Court of Canada took a stricter approach to the offence of sexual assault than did the Alberta Court of Appeal.

See Soldier Settlement, supra note 54 and Re Firearms, supra note 51.

See Westendorp, supra note 12 and Re Proposed Federal Tax, supra note 54.

See $C N T$, supra note 43.

See $R$. v. Gee, [1982] 2 S.C.R. 286, affg (1980), 26 A.R. 212: Faid, supra note 24; and R. v. Milne. [1992] I S.C.R. 697, rev'g (1990), 109 A.R. 268.

See Faid, supra note 24 and $R$. v. Milne, ibid.

See $R$. v. Gee, supra note 60.

See Park, supra note 26 and Ewanchuk, supra note 1. 
In the three cases concerning young offenders legislation ${ }^{64}$ two criticisms appeared in dissenting reasons, ${ }^{65}$ and one criticism appeared in the majority reasons. ${ }^{66}$ All criticisms occurred in cases in which the appeal was dismissed. The criticism appearing in the majority reasons is classified as identifying a legal error, but the criticisms appearing in the dissents are categorized as identifying a serious legal error ${ }^{67}$ and a flagrant legal error. ${ }^{68}$ In each case the criticism suggests that the Alberta Court of Appeal, for various reasons, took too lax an approach in interpreting the protections afforded to an accused by the legislation: the criticisms each offer an interpretation which benefits the accused. These cases suggest that the Supreme Court of Canada was more liberal than the Alberta Court of Appeal in interpreting and applying the statutory protections offered to young offenders: the Supreme Court was more sympathetic to young offenders than was the Alberta Court of Appeal.

The remaining five cases ${ }^{69}$ are more difficult to fit within a narrow topic area, but these cases generally all involve the Supreme Court reviewing the appeal process. The appeals were allowed in each of these cases, with the negative comments appearing in two majority judgments ${ }^{70}$ and in three dissenting reasons. ${ }^{71}$ The tone of the comments in four of these cases falls within the misunderstanding of law category, ${ }^{72}$ with the criticisms in the remaining case falling within the serious misunderstanding of law category. ${ }^{73}$ Generally, the criticisms in each case related to the apparent willingness of the Alberta Court of Appeal to review the opinions of the trial judge and to allow access to the appeal process. The Supreme Court of Canada's comments, as a whole, suggest that the Court of Appeal should have been more discriminating in deciding whether certain issues were appealable to the court, in deciding what information should have been received by the Alberta Court of Appeal, and in deciding whether to substitute its own finding for that of the trial judge.

\section{Positive FeEdback: Compliments FROM THE SUPREME COURT OF CANADA}

While most of this article has been devoted to a discussion of the Supreme Court's criticisms of the Alberta Court of Appeal's reasoning, an analysis of the relationship between these two courts would not be complete without recognition of the occasions when the Supreme Court has expressly complimented the Court of Appeal's reasoning.

See $R$. v. M.(S.H.), [1989] 2 S.C.R. 446, affg (1987), 78 A.R. 309 [hereinafter SHM]; JEL, supra note 25; and $R$. v. D.A.Z. [1992] 2 S.C.R. 1025, affg (1991), 117 A.R. 75 [hereinafter DAZ]. See $S H M$ and $J E L$, ibid.

(x. See DAZ, supra note 64 .

67. See SHM, supra note 64.

6 See JEL, supra note 64.

6) See $R$. v. Leaney, [1989] 2 S.C.R. 393, rev'g (1991), 117 A.R. 202 [hereinafter Leaney]; R. v. A.W.E., [1993] 3 S.C.R. 155, rev'g (1991), 120 A.R. 63 [hereinafter $A W E$ ]; R. v. Morin, [1992] 3 S.C.R. 286, rev'g (1991), 117 A.R. 36 [hereinafter Morin]. Re Judicature Act, supra note 24; and R. v. Al Klippert Lid. [1998] I S.C.R. 737, rev'g (1996), 187 A.R. 241 [hereinafter Al Klippert Lid.]. 
Of the 132 public law cases considered, such compliments appear in only two cases. First, in R. v. Big M Drug Mart the Supreme Court dismissed an appeal from the Alberta Court of Appeal that held the Lord's Day Act violated s. 2(a) of the Charter. Justice Dickson, writing for a majority of the Supreme Court, stated that "[ $t]$ he two judgments delivered [by the Court of Appeal] reflect, with clarity, the conflicting values, concerns and interests raised in this litigation." ${ }^{74}$ Second, in United Nurses of Alberta v. Alberta (A.G.) ${ }^{75}$ the Supreme Court's complimentary comments about the Court of Appeal analysis were expressed in the dissenting reasons and were made about the dissenting opinion at the Court of Appeal level. Specifically, Justice Sopinka, writing one of the Supreme Court's dissenting reasons, stated that the dissenting judge at the Court of Appeal was aware of the "danger" of "unrestrained use of criminal contempt proceedings in labour relations matters" giving "rise to the perception that the courts are interfering" and "rightly recognized that it would be 'unseemly' for the courts to utilize criminal contempt in these situations. ${ }^{176}$ Obviously, while being complimentary of the dissenting judgment at the Court of Appeal, Justice Sopinka's comments are also indirectly critical of the analysis of the majority of the Court of Appeal and the majority of the Supreme Court.

\section{Meaning and Message: Analyzing the Data}

Clearly, the data offered in this article can be analyzed in a myriad of ways, some of which have been addressed. For example, the cases can be scrutinized according to the success rate of the appeals, the judges writing the comments, whether the comments appear in the majority or dissenting opinion, the public law issues involved, and the tone or quality of the Supreme Court's negative commentary. The infinite possibilities for analyzing the data and the subjective nature of the material under consideration makes difficult the task of arriving at a clear picture of the public policy perspectives of the Supreme Court of Canada and the Alberta Court of Appeal. Still, recognizing that the information under consideration does not remotely lend itself to precise scientific analysis, the data does suggest a pattern to the manner in which each court approaches certain public law questions. Some general observations can be made regarding the relationship between the two courts during the eighteen-year period from 1982-2000.

First, the data demonstrates that the Supreme Court of Canada has not been reluctant to openly criticize the reasoning of the Alberta Court of Appeal on public law issues. While some justices seem more willing to offer such criticism than others, the Supreme Court's censure of the lower court in the Ewanchuk case is not unique. At most Ewanchuk may be cited as a relatively rare but certainly not aberrant example of the Supreme Court accusing the Court of Appeal of a serious or flagrant misunderstanding of the law.

Second, although the results of the cases diverge considerably, the data suggests that the Supreme Court's public law analysis has most clearly differed from that of the Alberta Court of Appeal with respect to constitutional questions relating to the division of powers. The Supreme Court of Canada has frequently criticized the Alberta Court of Appeal's 
support of strong provincial powers. This difference in perspective between the courts is accentuated by the fact that the Supreme Court's criticism on division of powers matters has typically been strongly worded.

Third, the Supreme Court of Canada generally seems to have had a more liberal perspective than the Alberta Court of Appeal in applying the Charter. That is, the Supreme Court of Canada has applied the Charter more readily than the Alberta Court of Appeal. Surprisingly, the Supreme Court has been somewhat restrained in the tone of its criticism of the Alberta Court of Appeal on Charter matters, even where the point of disagreement is fundamental as, for example, in the Vriend case.

Fourth, in criminal law matters the Supreme Court of Canada seems to have taken a more strict approach to adult crime, especially in regards to sexual assault. The situation is reversed with respect to youth crime, where the Supreme Court of Canada appears to have been more sympathetic to the alleged offender than the Alberta Court of Appeal has been. Judging from the tone of the Supreme Court's criticisms, the divergence of opinion between the courts on sexual assault and youth crime issues has been significant.

Fifth, in matters of access to appeals and evidence to be heard on appeal the Supreme Court of Canada generally has taken a more stringent approach than that taken by the Alberta Court of Appeal. The Supreme Court of Canada seems to have viewed the appeal procedures as narrow and subject to close review. In contrast, the Alberta Court of Appeal appears to have been more willing to stretch the rules and give the benefit of the doubt to the appellant with respect to the appeal processes.

Finally, on the specific matter that prompted this research project, the Ewanchuk decision does not represent a unique instance of a clash between Justices L'Heureux Dubé and McClung. The data shows that Justice L'Heureux Dubé has been the most critical Supreme Court justice. Justice McClung has been the most frequently criticized Court of Appeal justice. The Supreme Court and the Court of Appeal have often disagreed on issues of consent in sexual assault cases. Consequently, although it is difficult to draw definitive conclusions from the data, it appears that, given the judicial personalities involved and the subject matter of the case, Ewanchuk was destined to produce a clash between the Courts, which ultimately found itself played out in the pages of the daily newspapers.

\section{Conclusions}

This article has attempted to shed some light on the nature of the relationship between the Alberta Court of Appeal and the Supreme Court of Canada and the extent of disagreements between the Courts on public law issues. The attention given to an analysis of this relationship was merited largely by the public attention drawn to the divergent opinions of the two courts in the Ewanchuk case. Although judicial personalities no doubt played some role in defining this dispute, the data reviewed in this study, covering public law cases from 1982 to 2000 , indicates that the relationship between the courts on public law matters has been at least equally defined by some fundamental philosophical differences between the courts regarding public law issues. Of course, a more definitive 
and complete picture of these philosophical differences could be obtained by comparing the data regarding the Supreme Court's criticism of the Alberta Court of Appeal with similar data regarding the Supreme Court of Canada's negative criticism of other provincial appeal courts. Such an analysis, however, will have to wait for a future paper.

\section{APPENDIX A}

\section{all Public law Cases appealed to the SUPREME COURT OF CANADA From THE AlbERTA COURT OF APPEAL FROM 1982 TO DECEMBER, 2000}

Note: The 21 public law cases foumd to comtain over negative commentary by the Sitpreme (ourt regarding the Alberla (onurt of Appeal 's reasoming ane marked in bold. For the Reswll of each case. "AI)" means appeal dismissed amd "AA" means appeal allowed.

\begin{tabular}{|c|c|c|c|c|c|}
\hline Case Name & Year & Result & Charter & Non-Charter & Other \\
\hline $\begin{array}{l}\text { R. v. Gee, [1982] } 2 \text { S.C.R. 286. aff g } \\
\text { (1980), } 26 \text { A.R. } 212\end{array}$ & 1982 & $A D$ & & & $\begin{array}{l}\text { s. } 27 \text { ('riminal } \\
\text { code (")( (") }\end{array}$ \\
\hline $\begin{array}{l}\text { R. v. Sweilzer, [1982] I S.C.R. } 949 . \\
\text { rev'g (1980), } 26 \text { A.R. } 208\end{array}$ & 1982 & $\mathbf{A A}$ & & & $\begin{array}{l}\text { admissibility } \\
\text { of similar fact } \\
\text { evidence }\end{array}$ \\
\hline $\begin{array}{l}\text { R. v. Lowden, [1982] } 2 \text { S.C.R. } 60 \text {, } \\
\text { aff g (1981), } 27 \text { A.R. } 91\end{array}$ & 1982 & $A D$ & & & $\begin{array}{l}\text { ss. } 283.290 \text {, } \\
292 C^{\prime}\left(C^{\prime}\right.\end{array}$ \\
\hline $\begin{array}{l}\text { Reference Re Proposed Federal Tax } \\
\text { on Exported Natural Gas, [1982] I } \\
\text { S.C.R. 1004, aff'g (1981) } 28 \text { A.R. II }\end{array}$ & 1982 & $A D$ & & ss. $91(2), 125$ & \\
\hline $\begin{array}{l}\text { R. v. Brown, [1982] I S.C.R. } 859 \text {, } \\
\text { rev'g (1981), } 23 \text { C.R. (3d) } 313\end{array}$ & 1982 & $\mathbf{A A}$ & & & $\begin{array}{l}\text { admission of } \\
\text { new evidence } \\
\text { on appeal }\end{array}$ \\
\hline $\begin{array}{l}\text { Camadu (N.P.B) v. Moone, [1983] I } \\
\text { S.C.R. 658, rev'g (1983), } 45 \text { A.R. } 163\end{array}$ & 1983 & AA & & & $\begin{array}{l}\text { s. } 16 \text { Parole } \\
\text { Act }\end{array}$ \\
\hline $\begin{array}{l}\text { R. v. Faid, [1983] l S.C.R. 265, rev'g } \\
\text { (1981), } 30 \text { A.R. } 616\end{array}$ & 1983 & AA & & & $\begin{array}{l}\text { ss. } 34(2), 215 \\
\text { C }^{\prime}\end{array}$ \\
\hline $\begin{array}{l}\text { R. v. Westendorp, [1983] I } 43 \text { S.C.R. } \\
\text { rev'g (1982), } 35 \text { A.R. } 228\end{array}$ & 1983 & AA & & $\begin{array}{l}\text { ss. } 91(27) \text {, } \\
92(16)\end{array}$ & \\
\hline $\begin{array}{l}\text { R. v. Konkin. [1983] I S.C.R. } 388 . \\
\text { afT' }(1981), 31 \text { A.R. } 518\end{array}$ & 1983 & $A D$ & & & s. $142(C$ \\
\hline $\begin{array}{l}\text { Canada (A.G.) v. Canadian National } \\
\text { Transportation, [1983] } 2 \text { S.C.R. 206, } \\
\text { rev'g (1985), } 60 \text { A.R. } 380\end{array}$ & 1983 & $\mathbf{A A}$ & & $\begin{array}{l}\text { ss. } 91(27) \text {, } \\
91(2), 92(14) \text {. } \\
\text { and POGG }\end{array}$ & \\
\hline $\begin{array}{l}\text { R. v. Duhamel, [1984] } 2 \text { S.C.R. } 555 . \\
\text { aff'g (1981). } 33 \text { A.R. } 271\end{array}$ & 1984 & $A D$ & & & $\begin{array}{l}\text { res.judicala \& } \\
\text { voir dire }\end{array}$ \\
\hline $\begin{array}{l}\text { R. v. (ardinal, [1984] } 2 \text { S.C.R. } 523 \text {, } \\
\text { aff g (1982), } 42 \text { A.R. } 180\end{array}$ & 1984 & $A D$ & & & $\begin{array}{l}\text { ss. } 144.147 \\
\text { ('. }\end{array}$ \\
\hline
\end{tabular}




\begin{tabular}{|c|c|c|c|c|c|}
\hline Case Name & Year & Result & Charter & Non-Charter & Other \\
\hline $\begin{array}{l}\text { R. v. Brese, [1984] } 2 \text { S.C.R. 333, } \\
\text { aff'g (1982), } 37 \text { A.R. } 614\end{array}$ & 1984 & $A D$ & & & $\begin{array}{l}\text { s. } 178.13(2) \\
\text { (c. }\end{array}$ \\
\hline $\begin{array}{l}\text { R. v. Wis Developmem (iorp., [1984] } \\
\text { I S.C.R. 485, aff g [1981] A.J. No. } 7 \text { I } \\
\text { (QL) }\end{array}$ & 1984 & $A D$ & & & s. $510 C^{\circ}$ \\
\hline $\begin{array}{l}\text { Hunter v. Southam Inc. [ [1984] } 2 \\
\text { S.C.R. 145, aff'g (1983), } 42 \text { A.R. } 93\end{array}$ & 1984 & $A D$ & $\begin{array}{l}\text { ss. } 10(1) \\
10(3)\end{array}$ & & \\
\hline $\begin{array}{l}\text { Reference Re Judicature } \\
\text { ACt(Alberta), s. 27(1), [1984] } 2 \text { S.C.R. } \\
\text { 697, rev'g (1983), 50 A.R. I }\end{array}$ & 1984 & $A A$ & & & s. $178 \mathrm{C} C$ \\
\hline $\begin{array}{l}\text { R. v. Oshome, [1984] 2 S.C.R. } 406 \text {, } \\
\text { aff'g ABCA. (24 August 1982) \& (28 } \\
\text { January 1983) unreported }\end{array}$ & 1984 & $A D$ & & & $\begin{array}{l}\text { evidence } \\
\text { admission }\end{array}$ \\
\hline $\begin{array}{l}\text { Plamiation Indoor Planis Lid. v. } \\
\text { Alhera (A.(j.), [1985] I S.C.R. } 366 \text {, } \\
\text { rev'g (1982), } 34 \text { A.R. } 348\end{array}$ & 1985 & $\mathbf{A A}$ & & & $\begin{array}{l}\text { injunction to } \\
\text { enforce } \\
\text { criminal law }\end{array}$ \\
\hline $\begin{array}{l}\text { R. v. Terlecki, [1985] } 2 \text { S.C.R. } 483 \text {, } \\
\text { aff g (1983), } 42 \text { A.R. } 87\end{array}$ & 1985 & $A D$ & & & $\begin{array}{l}\text { multiple } \\
\text { convictions }\end{array}$ \\
\hline $\begin{array}{l}\text { R. v. Rahm, [1985] I S.C.R. } 659 . \\
\text { rev'g (1984), } 50 \text { A.R. } 43\end{array}$ & 1985 & AA & ss. 10,24 & & \\
\hline $\begin{array}{l}\text { R. v. Brown, [1985] } 2 \text { S.C.R. } 273 . \\
\text { aff g (1982), } 41 \text { A.R. } 69\end{array}$ & 1985 & $A D$ & & & $\begin{array}{l}\text { improper } \\
\text { cross-examine } \\
\text { at trial }\end{array}$ \\
\hline $\begin{array}{l}\text { R. v. Hone \& Pilfield Foods, [1985] } \\
\text { I S.C.R. 364, aff g (1982), } 39 \text { A.R. } \\
428\end{array}$ & 1985 & AD & & & $\begin{array}{l}\text { s. Is Lord's } \\
\text { Day ACt } \\
\text { interpretation }\end{array}$ \\
\hline $\begin{array}{l}\text { R. v. Big M Drigg Marr L.dd.[1985] I } \\
\text { S.C.R. 295, aff' (1983). } 49 \text { A.R. } 194\end{array}$ & 1985 & $A D$ & s. 2(a) & & \\
\hline $\begin{array}{l}\text { R. v. Towne ('inema Thealres I.dd, } \\
\text { [1985] I S.C.R. 494, rev'g (1984), } 42 \\
\text { A.R. } 284\end{array}$ & 1985 & AA & & & s. $159(8)(C$ \\
\hline $\begin{array}{l}\text { R. v. Duhois, [1985] } 2 \text { S.C.R. } 350 . \\
\text { rev'g (1987), } 83 \text { A.R. } 161\end{array}$ & 1985 & AA & s. 13 & & \\
\hline $\begin{array}{l}\text { Deloille Haskins \& Sclls I.d. v. } \\
\text { Albertu (W.C.B.). [1985] I S.C.R. } \\
\text { 785, rev'g (1983), } 43 \text { A.R. 24I }\end{array}$ & 1985 & $\mathbf{A A}$ & & $\begin{array}{l}\text { conflict of } \\
\text { Bomknuptcy Act } \\
\text { \& Alberta } \\
\text { Worker's } \\
\text { ('ompensulion } \\
\text { Act }\end{array}$ & \\
\hline $\begin{array}{l}\text { R. v. Duane. [1985] } 2 \text { S.C.R. } 612 . \\
\text { aff g (1984), } 57 \text { A.R. } 227\end{array}$ & 1985 & $A D$ & & & s. $408(b) c^{\circ}$ \\
\hline $\begin{array}{l}\text { (NI v. Alherta (A.G.), [1986] } 2 \\
\text { S.C.R. 711, aff g (1985), } 60 \text { A.R. } 380\end{array}$ & 1986 & AD & s. 11 (b) & & \\
\hline
\end{tabular}




\begin{tabular}{|c|c|c|c|c|c|}
\hline Case Name & Year & Result & Charter & Non-Charter & Other \\
\hline $\begin{array}{l}\text { R. v. Neliring. [1986] } 2 \text { S.C.R. } 709 . \\
\text { aff g (1984). } 51 \text { A.R. } 215\end{array}$ & 1986 & $A D$ & & & $\begin{array}{l}\text { ss. } 34(2) .40 \\
\text { (C. }^{-3}\end{array}$ \\
\hline $\begin{array}{l}\text { R. v. Mammion. [1986] } 2 \text { S.C.R. } 272 . \\
\text { aff g (1985). } 53 \text { A.R. } 81\end{array}$ & 1986 & $A D$ & s. 13 & & \\
\hline $\begin{array}{l}\text { R. v. Morveuk, [1986] I S.C.R. 31. } \\
\text { affg, ABCA unreported }\end{array}$ & 1986 & $A D$ & & & $\begin{array}{l}\text { Nanconics } \\
\text { Commmol Act }\end{array}$ \\
\hline $\begin{array}{l}\text { R. v. Jones, [1986] } 2 \text { S.C.R. } 284 . \\
\text { aff g (1984), } 57 \text { A.R. } 266\end{array}$ & 1986 & $A D$ & ss. 2(a), 7 & & \\
\hline $\begin{array}{l}\text { Reference Re Public Sentice Limployee } \\
\text { Relations Act (Alherra), [1987) I } \\
\text { S.C.R. 313, affg (1984), } 57 \text { A.R. } 268\end{array}$ & 1987 & $A D$ & s. 2(d) & & \\
\hline $\begin{array}{l}\text { R. v. Aiello, [1987] } 2 \text { S.C.R. } 462 \text {. } \\
\text { affg (1986), } 82 \text { A.R. } 393\end{array}$ & 1987 & AD & & & judicial error \\
\hline $\begin{array}{l}\text { R. v. Doz, [1987] } 2 \text { S.C.R. 463, rev'g } \\
\text { (1985), } 59 \text { A.R. } 185\end{array}$ & 1987 & $\mathrm{AA}$ & $\begin{array}{l}\text { ss. } \|(d) \\
\|(f)\end{array}$ & & \\
\hline $\begin{array}{l}\text { R. v. Vermeelle. [1987] I S.C.R. } 577 . \\
\text { afrg (1983). } 44 \text { A.R. } 253\end{array}$ & 1987 & $A D$ & & & s. $8\left(C^{\circ}\right.$ \\
\hline $\begin{array}{l}\text { R. v. Sieme, [1988] I S.C.R. 1093, } \\
\text { affg (1986), } 67 \text { A.R. } 34\end{array}$ & 1988 & $A D$ & & & $\begin{array}{l}\text { delay in } \\
\text { reporting } \\
\text { sexual assault }\end{array}$ \\
\hline $\begin{array}{l}\text { R. v. Jucuhs, [1988] 2 S.C.R. } 1047 \text {. } \\
\text { affg (1987), } 77 \text { A.R. } 253\end{array}$ & 1988 & $A D$ & s. $24(1)$ & & \\
\hline $\begin{array}{l}\text { R. v. Buchmom, [1988] I S.C.R. 1094, } \\
\text { affg (1987), } 78 \text { A.R. } 282\end{array}$ & 1988 & $A D$ & & & $\begin{array}{l}\text { reasonable } \\
\text { notice re } \\
\text { evidence }\end{array}$ \\
\hline $\begin{array}{l}\text { R. v. lafframce, [1988] I S.C.R. } 617 . \\
\text { aff g [1986] A.J. No. } 1102 \text { (QL) }\end{array}$ & 1988 & $A D$ & & & $\begin{array}{l}\text { interception } \\
\text { authorization }\end{array}$ \\
\hline $\begin{array}{l}\text { R. v. Sireu, [1989] I S.C.R. IS21. } \\
\text { aff g (1987). } 76 \text { A.R. } 381\end{array}$ & 1989 & $A D$ & & & $\begin{array}{l}\text { hearsay } \\
\text { evidence }\end{array}$ \\
\hline $\begin{array}{l}\text { R. v. lemb, [1989] I S.C.R. 1036, } \\
\text { aff g (1987), } 78 \text { A.R. } 252\end{array}$ & 1989 & $A D$ & 5.8 & & \\
\hline $\begin{array}{l}\text { R. v. Mc(jimm. [1989] I S.C.R. 1035, } \\
\text { rev'g (1987). } 78 \text { A.R. } 247\end{array}$ & 1989 & $\mathbf{A A}$ & & & $\begin{array}{l}\text { trafficking } \\
\text { offence }\end{array}$ \\
\hline $\begin{array}{l}\text { R. v. Nygauml, [1989] } 2 \text { S.C.R. } 1074 . \\
\text { rev'g (1987), } 78 \text { A.R. } 389\end{array}$ & 1989 & $\mathbf{A A}$ & & & $\begin{array}{l}\text { ss. } 212.214 . \\
178.16 C^{\circ}\end{array}$ \\
\hline $\begin{array}{l}\text { Black v. Law Sociefy Alberia, [1989] } \\
\text { I S.C.R. 591, aff g (1986). } 68 \text { A.R. } \\
259\end{array}$ & 1989 & $A D$ & s. 6 & & \\
\hline $\begin{array}{l}\text { R. v. M.(S.H.), [1989] } 2 \text { S.C.R. 446, } \\
\text { aff g (1987). } 78 \text { A.R. } 309\end{array}$ & 1989 & $A D$ & & & $\begin{array}{l}\text { s. } 16 \text { Yommig } \\
\text { Offenders: } A c t \\
\text { ("YOA") }\end{array}$ \\
\hline $\begin{array}{l}\text { R. v. } L(J . E .),[1989] 2 \text { S.C.R. } 510 \text {, } \\
\text { aff g [1987] A.J. No. } 1124 \text { (QL) }\end{array}$ & 1989 & AD & & & s. $16 Y O A$ \\
\hline
\end{tabular}




\begin{tabular}{|c|c|c|c|c|c|}
\hline Case Name & Year & Result & Charter & Non-Charter & Other \\
\hline $\begin{array}{l}\text { R. v. Szlovak, [1989] } 2 \text { S.C.R. III4, } \\
\text { aff, (1989), } 96 \text { A.R. } 73\end{array}$ & 1989 & $A D$ & $\begin{array}{l}\text { ss. } 8.10(a) \text {, } \\
24(2)\end{array}$ & & \\
\hline $\begin{array}{l}\text { Moysa v. Alherra (L.R.B.), [1989] I } \\
\text { S.C.R. I572. affg (1987). } 79 \text { A.R. } \\
\text { I18 }\end{array}$ & 1989 & $A D$ & s. $2(b)$ & & \\
\hline $\begin{array}{l}\text { R. v. Heikel, [1989] I S.C.R. } 1776 \text {, } \\
\text { affg (1990), } 110 \text { A.R. } 161\end{array}$ & 1989 & $A D$ & ss. 10 (b). 11 & & \\
\hline $\begin{array}{l}\text { R. v. Lambrella, [1989] I S.C.R. } \\
\text { 1391, aff g (1987), } 78 \text { A.R. } 284\end{array}$ & 1989 & $\mathrm{AD}$ & ss. $11(d) .7$ & & \\
\hline $\begin{array}{l}\text { ('handler v. Association of Archilecis } \\
\text { Alherna. [1989] 2 S.C.R. 848, aff g } \\
\text { (1985), 62 A.R. } 72\end{array}$ & 1989 & $A D$ & & & $\begin{array}{l}\text { finchus } \\
\text { principle }\end{array}$ \\
\hline $\begin{array}{l}\text { Brosseau v. Alherna (Securifies } \\
\text { Commissiom), [1989] I S.C.R. 30I, } \\
\text { aff g (1986), } 67 \text { A.R. } 222\end{array}$ & 1989 & $A D$ & & & Securitics $A c t$ \\
\hline $\begin{array}{l}\text { R. v. Leaney. [1989] } 2 \text { S.C.R. } 393 \text {, } \\
\text { rev'g (1988), } 117 \text { A.R. } 202\end{array}$ & 1989 & AA & & & s. $613\left(C^{\circ}\right.$ \\
\hline $\begin{array}{l}\text { R. v. Keegstra } \\
\text { [1990] } 3 \text { S.C.R. 697, rev'g (1988), } 87 \\
\text { A.R. } 177\end{array}$ & 1990 & AA & ss. 2 (b), 11 (d) & & \\
\hline $\begin{array}{l}\text { Mahe v. Alherta, [1990] I S.C.R. } 342 . \\
\text { rev'g (1987), } 80 \text { A.R. } 161\end{array}$ & 1990 & AA & s. $23(3)$ & & \\
\hline $\begin{array}{l}\text { R. v. Brydges, [1990] I S.C.R. 190, } \\
\text { rev'g (1987), 81 A.R. } 273\end{array}$ & 1990 & AA & $\begin{array}{l}\text { ss. 10(b), } \\
24(2)\end{array}$ & & \\
\hline $\begin{array}{l}\text { R. v. B. (C:R.) [Burrell], [1990] 1 } \\
\text { S.C.R. 717, aff'g (1987), } 82 \text { A.R. } 45\end{array}$ & 1990 & $A D$ & & & $\begin{array}{l}\text { evidence } \\
\text { admissibility }\end{array}$ \\
\hline $\begin{array}{l}\text { R. v. (ineffe, [1990] I S.C.R. } 755 \text {, } \\
\text { rev'g (1988), } 84 \text { A.R. } 96\end{array}$ & 1990 & AA & s. 8 & & \\
\hline $\begin{array}{l}\text { R. v. Horvemam, [1990] I S.C.R. } 901 \text {, } \\
\text { aff' (1987), } 78 \text { A.R. } 35 \text { । }\end{array}$ & 1990 & $A D$ & & $\begin{array}{l}\text { Alberta Wildlife } \\
\text { Act \& Netural } \\
\text { Resusurce } \\
\text { Trumsfer } \\
\text { Agreememe }\end{array}$ & \\
\hline $\begin{array}{l}\text { R. v. Wilson, [1990] I S.C.R. 1291, } \\
\text { aff g (1987). } 76 \text { A.R. } 315\end{array}$ & 1990 & $A D$ & s. 9 & & \\
\hline $\begin{array}{l}\text { Ceninal Alherra Dainy Pool v. Alheral } \\
\text { (H.R.C.). [1990] } 2 \text { S.C.R. 489, rev'g } \\
\text { (1988), III A.R. } 288\end{array}$ & 1990 & $\mathbf{A A}$ & & & $\begin{array}{l}\text { Imdividual } \\
\text { Rights } \\
\text { Protection Act } \\
\text { ("IRPA") }\end{array}$ \\
\hline $\begin{array}{l}\text { R. v. Wallen } \\
\text { [1990] I S.C.R. 827, rev'g (1988), } 84 \\
\text { A.R. } 12\end{array}$ & 1990 & $A A$ & & & $\begin{array}{l}\text { defences to } \\
\text { imurder }\end{array}$ \\
\hline $\begin{array}{l}\text { K. v. Smith, [1990] I S.C.R. 991, } \\
\text { affg (1989), } 95 \text { A.R. } 304\end{array}$ & 1990 & $A D$ & & & alibi onus \\
\hline
\end{tabular}




\begin{tabular}{|c|c|c|c|c|c|}
\hline Case Name & Year & Result & Charter & Non-Charter & Other \\
\hline $\begin{array}{l}\text { R. v. Siagnilla, [1990] I S.C.R. 1226, } \\
\text { aff'g (1987), } 79 \text { A.R. } 44\end{array}$ & 1990 & $A D$ & ss. 2 (b), 7 & & \\
\hline $\begin{array}{l}\text { R. v. Murtineam, [1990] } 2 \text { S.C.R. } 633 \text {, } \\
\text { aff g (1988), } 89 \text { A.R. } 162\end{array}$ & 1990 & $A D$ & ss. 7,11 (d) & & \\
\hline $\begin{array}{l}\text { R. v. Luxion, [1990] } 2 \text { S.C.R. 7II, } \\
\text { aff'g (1989), 111 A.R. 16] }\end{array}$ & 1990 & $A D$ & $\begin{array}{l}\text { ss. } 7,11(d) \\
9.12\end{array}$ & & \\
\hline $\begin{array}{l}\text { R. v. Paquetle, [1990] } 2 \text { S.C.R. } 1103 \text {, } \\
\text { aff } \mathrm{g} \text { (1987), } 81 \text { A.R. } 12\end{array}$ & 1990 & $A D$ & & & $\begin{array}{l}\text { s. } 110 \mathrm{NWT} \\
\mathrm{Acl}\end{array}$ \\
\hline $\begin{array}{l}\text { R. v. Shupe, [1990] } 2 \text { S.C.R. } 1108 \text {, } \\
\text { aff g (1988), } 85 \text { A.R. } 73\end{array}$ & 1990 & $A D$ & s. $11(d)$ & & \\
\hline $\begin{array}{l}\text { R. v. Broyles, [199]] } 3 \text { S.C.R. 595, } \\
\text { rev'g (1987), } 82 \text { A.R. } 238\end{array}$ & 1991 & $\mathrm{AA}$ & s. 7 & & \\
\hline $\begin{array}{l}\text { R. v. Sinchcombe, [1991] 3 S.C.R. } \\
\text { 326, rev'g [1990] A.W.L.D. } 519\end{array}$ & 1991 & AA & s. 7 & & \\
\hline $\begin{array}{l}\text { R. v. } F_{\text {( }}(H .) / H . F . /,[1991] \text { 3 S.C.R. } \\
\text { 322. afr } \mathrm{g}(1990), \text { I05 A.R. } 135\end{array}$ & 1991 & $A D$ & & & $\begin{array}{l}\text { s. } 246.5(33) \\
\text { ( }(: .\end{array}$ \\
\hline $\begin{array}{l}\text { R. v. Meddoui, [1991] } 3 \text { S.C.R. } 320 \text {, } \\
\text { aff g (1990), } 111 \text { A.R. } 295\end{array}$ & 1991 & $\mathrm{AD}$ & & & $\begin{array}{l}281 \mathrm{C}(\mathrm{S} \\
16(3) \text { Cansola } \\
\text { Evidence } \mathrm{ACl}\end{array}$ \\
\hline $\begin{array}{l}\text { R. v. Sheridan, [1991] } 2 \text { S.C.R. } 205 \text {, } \\
\text { rev'g (1990), I05 A.R. } 122\end{array}$ & $199 \mid$ & $\mathbf{A A}$ & & & s. $232\left(C^{\circ}\right.$ \\
\hline $\begin{array}{l}\text { Canada (Director of Soldier } \\
\text { Settlement) v. Snider Estate, [1991] } 2 \\
\text { S.C.R. 481, aff' (1988), } 88 \text { A.R. } 385\end{array}$ & 1991 & $A D$ & & $\begin{array}{l}\text { s. } 57 \text { Soldier } \\
\text { Setllement ACt } \\
\text { \& Alberta lamd } \\
\text { Tille. Acl }\end{array}$ & \\
\hline $\begin{array}{l}\text { R. v. Milne, [1992] I S.C.R. } 697 \text {, } \\
\text { rev'g (1990), } 109 \text { A.R. } 268\end{array}$ & 1992 & $\mathbf{A A}$ & 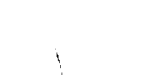 & & s. $322 C(C$ \\
\hline $\begin{array}{l}\text { R. v. Morin. [1992] } 3 \text { S.C.R. } 286 \text {, } \\
\text { rev'g (1991), } 117 \text { A.R. } 36\end{array}$ & 1992 & $\mathbf{A A}$ & & & $\begin{array}{l}\text { what is a } \\
\text { question of } \\
\text { law? }\end{array}$ \\
\hline $\begin{array}{l}\text { R. v. (juthrie [1992] } 2 \text { S.C.R. } 222 \text {, } \\
\text { affg (1991), } 114 \text { A.R. } 355\end{array}$ & 1992 & $A D$ & & & $\begin{array}{l}\text { elements of } \\
\text { fraud }\end{array}$ \\
\hline $\begin{array}{l}\text { R. v. D.A.Z., [1992] 2 S.C.R. } 1025 \text {, } \\
\text { affg (1991), } 117 \text { A.R. } 75\end{array}$ & 1992 & $\mathrm{AD}$ & & & s. $56 r() A$ \\
\hline $\begin{array}{l}\text { R. v. Dowmey, [1992] } 2 \text { S.C.R. } 10 \\
\text { affg (1990), } 105 \text { A.R. 351 }\end{array}$ & 1992 & $A D$ & s. $I I(d)$ & & \\
\hline $\begin{array}{l}\text { (inived Nurves of Alherta v. Alberla } \\
\text { (A.G.), [1992] I S.C.R. 901, aff'g } \\
\text { (1992), } 135 \text { A.R. } 148\end{array}$ & 1992 & $A D$ & s. 7 & & \\
\hline $\begin{array}{l}\text { R. v. Mellewhin. [1992] 3 S.C.R. 615. } \\
\text { rev'g (1991), II7 A.R. } 165\end{array}$ & 1992 & $\mathbf{A A}$ & ss. 8,9 & & \\
\hline
\end{tabular}




\begin{tabular}{|c|c|c|c|c|c|}
\hline Case Name & Year & Result & Charter & Non-Charter & Other \\
\hline $\begin{array}{l}\text { Dickason v. University of Alherwa, } \\
\text { [1992] } 2 \text { S.C.R. 1103, aff g (1991), } \\
\text { I17 A.R. II }\end{array}$ & 1992 & $A D$ & & & $\begin{array}{l}\text { ss. } 7,11.1 \\
I R I ' A\end{array}$ \\
\hline $\begin{array}{l}\text { Referunce Re (joods and Sunvices Tax } \\
\text { (GST), [1992] } 2 \text { S.C.R. 445, rev'g } \\
\text { (1991), } 117 \text { A.R. } 321\end{array}$ & 1992 & AA & & $\begin{array}{l}\text { ss. } 91(3), 103 \\
125,126 \\
92(13)\end{array}$ & \\
\hline $\begin{array}{l}\text { R. v. Steeves, [1993] I S.C.R. I136, } \\
\text { rev'g (1992), } 127 \text { A.R. } 2\end{array}$ & 1993 & AA & & & $\begin{array}{l}\text { verdict } \\
\text { reasonable }\end{array}$ \\
\hline $\begin{array}{l}\text { R. v. (jonculies, [1993] } 2 \text { S.C.R. } 3 \text {. } \\
\text { rev'g (1992), 131 A.R. } 68\end{array}$ & 1993 & AA & ss. $8,24(2)$ & & \\
\hline $\begin{array}{l}\text { R. v. Ericksom, [1993] } 2 \text { S.C.R. } 649 \text {, } \\
\text { rev'g (1992). } 125 \text { A.R. } 68\end{array}$ & 1993 & AA & ss. $8,24(2)$ & & \\
\hline $\begin{array}{l}\text { R. v. Honish, [1993] I S.C.R. } 458 \text {, } \\
\text { aff'g (1991), } 120 \text { A.R. } 223\end{array}$ & 1993 & AD & & & $\begin{array}{l}\text { defence inade } \\
\text { out? }\end{array}$ \\
\hline $\begin{array}{l}\text { R. v. Broun, [1993] } 2 \text { S.C.R. } 918, \\
\text { rev'g (1992), } 127 \text { A.R. } 89\end{array}$ & 1993 & AA & s. 7 & & \\
\hline $\begin{array}{l}\text { R. v. Komz, [1993] I S.C.R. 1134, } \\
\text { affg (1992), } 125 \text { A.R. } 161\end{array}$ & 1993 & AD & $s .11(d)$ & & \\
\hline $\begin{array}{l}\text { R. v. Price, [1993] } 3 \text { S.C.R. 633, affg } \\
\text { (1992). 13I A.R. } 54\end{array}$ & 1993 & $A D$ & & & $\begin{array}{l}\text { admission of } \\
\text { new evidence } \\
\text { on appeal }\end{array}$ \\
\hline $\begin{array}{l}\text { R. v. ligger. [1993] } 2 \text { S.C.R. } 451 \text {. } \\
\text { rev'g (1991), } 120 \text { A.R. } 360\end{array}$ & 1993 & AA & & & ss. $258(1) \mathrm{C} \mathrm{C}^{\circ}$ \\
\hline $\begin{array}{l}\text { R. v. Evans, [1993] } 3 \text { S.C.R. } 653 \text {, } \\
\text { affg [1993] A.W.L.D. } 981\end{array}$ & 1993 & $A D$ & & & $\begin{array}{l}\text { hearsay } \\
\text { evidence }\end{array}$ \\
\hline $\begin{array}{l}\text { R. v. Plan, [1993] } 3 \text { S.C.R. 281, aff g } \\
\text { (1991), I16 A.R. ] }\end{array}$ & 1993 & $A D$ & ss.8. $24(2)$ & & \\
\hline $\begin{array}{l}\text { R. v. lichfield, [1993] } 4 \text { S.C.R. } 333 \text {, } \\
\text { rev'g (1992), I20 A.R. } 391\end{array}$ & 1993 & AA & & & $\begin{array}{l}\text { sexual assault } \\
\text { elements }\end{array}$ \\
\hline $\begin{array}{l}\text { R. v. Macooh, [1993] 2 S.C.R. } 802 \text {. } \\
\text { aff g (1991), } 117 \text { A.R. } 312\end{array}$ & 1993 & $A D$ & ss. 7.9 & & \\
\hline $\begin{array}{l}\text { R. v. A.W.E. [1993] 3 S.C.R. I55, } \\
\text { rev'g (1991), } 120 \text { A.R. } 63\end{array}$ & 1993 & $\mathbf{A A}$ & & & s. $682(1) C^{\circ}$ \\
\hline $\begin{array}{l}\text { R. v. Duhas:, [1994] 3 S.C.R. } 759 . \\
\text { rev'g (1994), } 149 \text { A.R. } 59\end{array}$ & 1994 & AA & & & s. $34(2)(C$ \\
\hline $\begin{array}{l}\text { R. v. Richer. [1994] } 2 \text { S.C.R. } 486 \text {, } \\
\text { affg (1993), } 141 \text { A.R. } 116\end{array}$ & 1994 & $A D$ & & & $\begin{array}{l}\text { s. } 231(5)(b) \\
\left(c^{\circ}\right.\end{array}$ \\
\hline $\begin{array}{l}\text { R. v. (ommen. [1994] } 2 \text { S.C.R. } 507 . \\
\text { aff } \text { (1993). I35 A.R. } 321\end{array}$ & 1994 & $A D$ & & & s. $166^{\circ} \circ^{\circ}$ \\
\hline $\begin{array}{l}\text { R. v. (ohham, [1994] 3 S.C.R. } 360 \text {, } \\
\text { rev'g (1993), } 135 \text { A.R. } 249\end{array}$ & 1994 & AA & $\begin{array}{l}\text { ss. } 10(b) \\
24(2)\end{array}$ & & \\
\hline
\end{tabular}




\begin{tabular}{|c|c|c|c|c|c|}
\hline Case Name & Year & Result & Charter & Non-Charter & Other \\
\hline $\begin{array}{l}\text { R. v. Zuzulak, [1994] } 2 \text { S.C.R. S, affg } \\
\text { (1993), } 145 \text { A.R. } 31\end{array}$ & 1994 & $A D$ & & & s. $131 C C^{\circ}$ \\
\hline $\begin{array}{l}\text { R. v. Ferris, [1994] 3 S.C.R. 756, } \\
\text { affg (1993), } 137 \text { A.R. } 154\end{array}$ & 1994 & $A D$ & & & licarsay \\
\hline $\begin{array}{l}\text { R. v. W.D.S., [1994] 3 S.C.R. 521, } \\
\text { rev'g [1993] A.U.D. } 909\end{array}$ & 1994 & AA & & & jury charge \\
\hline $\begin{array}{l}\text { R. v. (haplin, [1995] I S.C.R. } 727 \text {, } \\
\text { aff g (1993), } 145 \text { A.R. I53 }\end{array}$ & 1995 & AD & s.7 & & \\
\hline $\begin{array}{l}\text { R. v. Givddurd, [1995] I S.C.R. 854, } \\
\text { rev'g [1994] A.J. No. } 440 \text { (QL) }\end{array}$ & 1995 & AA & & & $\begin{array}{l}\text { obstruction of } \\
\text { justice }\end{array}$ \\
\hline $\begin{array}{l}\text { R. v. Johin, [1995] } 2 \text { S.C.R. 78, affg } \\
\text { (1992), 131 A.R. } 179\end{array}$ & 1995 & $A D$ & s. 7 & & \\
\hline $\begin{array}{l}\text { R. v. Sinchcombe, [1995] I S.C.R. } \\
\text { 754, affg (1994), } 149 \text { A.R. } 167\end{array}$ & 1995 & $A D$ & 5.7 & & \\
\hline $\begin{array}{l}\text { R. v. Park, [1995] } 2 \text { S.C.R. 836, rev'g } \\
\text { (1993), } 145 \text { A.R. } 207\end{array}$ & 1995 & AA & & & $\begin{array}{l}\text { "Air of } \\
\text { Reality" test in } \\
\text { sexual assault }\end{array}$ \\
\hline $\begin{array}{l}\text { R. v. Badger, [1996] I S.C.R. 771, } \\
\text { rev'g (1993), } 135 \text { A.R. } 286\end{array}$ & 1996 & $A A$ & & $\begin{array}{l}\text { s. } 35 \& \text { Treaty } \\
8\end{array}$ & \\
\hline $\begin{array}{l}\text { R. v. Patenuk. [1996] 3 S.C.R. } 607 . \\
\text { rev'g (1995). } 174 \text { A.R. } 129\end{array}$ & 1996 & AA & s. $10(b)$ & & \\
\hline $\begin{array}{l}\text { R. v. Keegsiru, [1996] I S.C.R. } 458 \text {, } \\
\text { rev'g (1996), } 187 \text { A.R. } 216\end{array}$ & 1996 & AA & s.7 & & \\
\hline $\begin{array}{l}\text { R. v. McConnel, [1996] I S.C.R. } \\
\text { l075, rev'g (1995), 169 A.R. } 32 \text { I }\end{array}$ & 1996 & AA & & & s. $34(2) C: C$ \\
\hline $\begin{array}{l}\text { R. v. Thiher. [1996] I S.C.R. } 37 \text {, } \\
\text { rev'g (1994), I57 A.R. } 316\end{array}$ & 1996 & $\mathbf{A A}$ & & & s. $232 C C^{\circ}$ \\
\hline $\begin{array}{l}\text { R. v. McMaster. [1996] I S.C.R. } 740 \text {, } \\
\text { rev'g [1994] A.J. No. } 754 \text { (QL) }\end{array}$ & 1996 & $\mathbf{A A}$ & & & $\begin{array}{l}\text { intoxication } \\
\text { defence }\end{array}$ \\
\hline $\begin{array}{l}\text { R. v. Bablitz, [1997] 3 S.C.R. } 1005 . \\
\text { aff'g [1996] A.J. No. } 215 \text { (QL) }\end{array}$ & 1997 & $A D$ & & & $\begin{array}{l}\text { previous } \\
\text { statements }\end{array}$ \\
\hline $\begin{array}{l}\text { R. v. ('hartand, [1997] 3 S.C.R. 1006, } \\
\text { aff g (1996). } 187 \text { A.R. 161 }\end{array}$ & 1997 & $A D$ & & & $\begin{array}{l}\text { prior criminal } \\
\text { record }\end{array}$ \\
\hline $\begin{array}{l}\text { R. v. Doliente, [1997] } 2 \text { S.C.R. II, } \\
\text { rev'g (1996). I84 A.R. I3I }\end{array}$ & 1997 & AA & & & $\begin{array}{l}\text { ss. } 343,268, \\
662\left(C^{\prime}\right.\end{array}$ \\
\hline $\begin{array}{l}\text { R. v. } L \mu,[1997] 2 \text { S.C.R. } 680 \text {, aff g } \\
\text { (1996), } 181 \text { A.R. } 192\end{array}$ & 1997 & $A D$ & s. 7 & & \\
\hline $\begin{array}{l}\text { Reference Re Remmenution of Judges } \\
\text { of the Provincial Courr. [1997] } 3 \\
\text { S.C.R. 3. rev'g (1995), } 169 \text { A.R. } 178\end{array}$ & 1997 & AA & s. II(d) & & \\
\hline $\begin{array}{l}\text { R. v. Honie. [1998] I S.C.R. 85, aff g } \\
\text { [1996] A.J. No. } 214 \text { (QL) }\end{array}$ & 1998 & $A D$ & & & jury instruction \\
\hline
\end{tabular}




\begin{tabular}{|c|c|c|c|c|c|}
\hline Case Name & Year & Result & Charter & Non-Charter & Other \\
\hline $\begin{array}{l}\text { R. v. (iellieur, [1998] I S.C.R. 1218, } \\
\text { aff'g (1997), } 196 \text { A.R. } 18\end{array}$ & 1998 & $A D$ & & & s. $475 \mathrm{CO}$ \\
\hline $\begin{array}{l}\text { R. v. (Indenirod. [1998] I S.C.R. } 77 . \\
\text { rev'g (1995), } 174 \text { A.R. } 234\end{array}$ & 1998 & AA & s. 7 & & \\
\hline $\begin{array}{l}\text { R. v. Jussila, [1998] I S.C.R. 755, } \\
\text { aff'g (1997), } 193 \text { A.R. } 292\end{array}$ & 1998 & $A D$ & & & $\begin{array}{l}\text { unreasonable } \\
\text { verdict }\end{array}$ \\
\hline $\begin{array}{l}\text { R. v. Al Klippert Lid. [1998] I } \\
\text { S.C.R. 737, rev'g (1996). } 187 \text { A.R. } \\
241\end{array}$ & 1998 & $\mathbf{A A}$ & & & $\begin{array}{l}\text { s. } 81 \text { Plamming } \\
\text { Acl }\end{array}$ \\
\hline $\begin{array}{l}\text { Vriend v. Alberta. [1998] I S.C.R. } \\
\text { 493, rev'g (1996). } 184 \text { A.R. 351 }\end{array}$ & 1998 & AA & s. 15 & & \\
\hline $\begin{array}{l}\text { R. v. Ewanchuk, [1999] I S.C.R. 330, } \\
\text { rev'g (1998), } 212 \text { A.R. } 81\end{array}$ & 1999 & AA & & & s. $265 \mathrm{CO}^{\circ}$ \\
\hline $\begin{array}{l}\text { R. v. Liew, [1999] } 3 \text { S.C.R. 227, rev'g } \\
\text { (1998). } 212 \text { A.R. } 38 \text { 1 }\end{array}$ & 1999 & $\mathbf{A A}$ & s. 7 & & \\
\hline $\begin{array}{l}\text { Reference Re Firearms Act, [2000] I } \\
\text { S.C.R. 783, aff g (1998), } 164 \text { D.L.R. } \\
\text { (4th) } 513\end{array}$ & 2000 & $A D$ & & $\begin{array}{l}\text { ss. } 91(27) \text {. } \\
92(13)\end{array}$ & \\
\hline $\begin{array}{l}\text { R. v. G.D.B.. [2000] I S.C.R. 520, } \\
\text { aff'g (1999). } 232 \text { A.R. } 307\end{array}$ & 2000 & AD & & & $\begin{array}{l}\text { evidence } \\
\text { admissibility }\end{array}$ \\
\hline $\begin{array}{l}\text { Puhlic lichool Boards' A.sw. of } \\
\text { Alherna v. Alhera (A.(j), [2000] I } \\
\text { S.C.R. 44, aff (1998), } 216 \text { A.R. } 249\end{array}$ & 2000 & $A D$ & & $\begin{array}{l}\text { ss. } 93 \& 17 \text { of } \\
\text { Alhertu } A C l\end{array}$ & \\
\hline $\begin{array}{l}\text { R. v. Russell [2000] } 2 \text { S.C.R. } 73 \text { ] } \\
\text { aff'g (1998), } 219 \text { A.R. } 19\end{array}$ & 2000 & AD & & & jury charge \\
\hline
\end{tabular}

